Working Paper 9518

\title{
UNDERSTANDING THE POSTWAR DECLINE IN UNITED STATES SAVING: A COHORT ANALYSIS
}

by Jagadeesh Gokhale, Laurence J. Kotlikoff, and John Sabelhaus

Jagadeesh Gokhale is an economic advisor at the Federal Reserve Bank of Cleveland, Laurence J. Kotlikoff is a professor of economics at Boston University and a research associate at the National Bureau of Economic Research, and John Sabelhaus is an economist at the Congressional Budget Office. The authors thank the Office of Management and Budget for providing critical data on long-range budget projections, and the Social Security Administration for furnishing U.S. population projections.

Working papers of the Federal Reserve Bank of Cleveland are preliminary materials circulated to stimulate discussion and critical comment. The views stated herein are those of the authors and are not necessarily those of the Federal Reserve Bank of Cleveland, the Board of Governors of the Federal Reserve System, or the Congressional Budget Office.

December 1995 


\begin{abstract}
The rate of saving in the United States has declined dramatically in recent decades. Since 1980, the U.S. net national saving rate has averaged just 4 percent. Since 1990, it has averaged just 2.4 percent--one-quarter the mean rate observed in the $1950 \mathrm{~s}$ and $60 \mathrm{~s}$. This paper develops a unique cohort data set to study the decline in U.S. national saving. It decomposes postwar changes in U.S. saving into those due to changes in cohort-specific consumption propensities, those due to changes in the intergenerational distribution of resources, those due to changes in the rate of government consumption, and those due to demographic changes.

Our findings are striking. The decline in U.S. saving can be traced to one major factor: The redistribution of resources from young and unborn generations with low or zero consumption propensities toward older generations with high consumption propensities. Most of the redistribution to the elderly reflects the growth in Social Security, Medicare, and Medicaid benefits. Although older generations' propensities to consume have increased significantly, those of younger generations have declined or remained constant over the last three decades. The increase in older Americans' consumption propensities may also reflect government policy, namely, the fact that Social Security benefits come in the form of annuities and that Medicare and Medicaid benefits are provided to the elderly directly in the form of consumption of medical goods and services.
\end{abstract}


clevelandfed.org/research/workpaper/index.cfm 


\section{Introduction}

In 1950 , the U.S. rate of net national saving was 12.3 percent. In 1993 , it was only 2.7 percent. 1 The difference in these saving rates illustrates a dramatic long-term decline in U.S. saving. The national saving rate averaged 9.1 percent per year in the $1950 \mathrm{~s}$ and $1960 \mathrm{~s}, 8.5$ percent in the $1970 \mathrm{~s}, 4.7$ percent in the $80 \mathrm{~s}$, and just 2.4 percent in the first four years of the $1990 \mathrm{~s}$.

The decline in U.S. saving has been associated with an equally dramatic decline in U.S. domestic investment. Since 1990, net domestic investment has averaged 3.1 percent per year, compared with 8.2 percent in the $1950 \mathrm{~s}$, 7.9 percent in the $1960 \mathrm{~s}$ and $1970 \mathrm{~s}$, and 6.1 percent in the 1980s. The low rate of domestic investment has limited growth in labor productivity and, consequently, growth in real wages. Since 1980, labor productivity has grown at less than half the rate observed between 1950 and 1979 , and total real compensation (wages plus fringe benefits) per hour has grown at only oneeighth its previously observed rate.

This paper develops a unique cohort data base to study the decline in U.S. saving. A key feature of these data is that they are bench-marked against national income accounts and other economic aggregates. Consequently, they relate directly to the change in net national saving measured by national income accounts. We use these cohort data within a simple life-cycle framework to decompose postwar changes in U.S. saving into those due to changes in the intergenerational distribution of resources, cohort-specific consumption propensities, the rate of government spending, and demographics.

Our findings are striking. Most of the decline in U.S. saving can be traced to one major factor: a redistribution of resources toward older genera-

1 The net national saving rate is defined as net national product less national consumption (household consumption plus government purchases), divided by net national product. 
tions, with high propensities to consume, from younger ones (including those not yet born), with low or zero propensities to consume. Much of the redistribution to the elderly appears to reflect the growth in government transfer payments. Older Americans' propensities to consume privately purchased as we11 as government-provided goods and services have increased tremendously. ${ }^{2}$ However, those of younger generations have exhibited an offsetting decline. As a result, despite the dramatic increase in the elderly cohorts' consumption propensities, the shift in cohort consumption propensities alone may not have led to the decline in saving witnessed over the last three decades.

This paper continues in Section II with a brief discussion of related research. Section III presents some stylized facts about recent trends in U.S. saving and consumption. Section IV describes our method for decomposing changes in national saving. Section $\mathrm{V}$ discusses data construction and data sources in general terms, relegating details to the Appendix. Section VI presents our findings, and Section VII draws conclusions.

\section{Related Studies}

Several recent studies of U.S. saving focus on Americans' personal saving, defined as saving out of disposable income. Summers and Carroll (1987) suggest that younger cohorts may be hoping to rely on Social Security benefits in their retirement and are consequently saving too little on their own. In contrast, Bosworth, Burtless, and Sabelhaus (1991) compare personal saving rates in the 1960s, 1970s, and 1980s and conclude that all age groups

2 The form taken by government transfers--the fact that they are annuitized and, in the case of health care, are in kind-may help explain the dramatic rise in elderly Americans' consumption propensities. 
are now saving at lower rates than before. Attanasio (1993) reaches a third conclusion. He places the blame for current low levels of personal saving on the failure of a particular subset of cohorts--those born between 1925 and 1939-to save.

The studies by Bosworth et al. and Attanasio use consumer expenditure data which directly cover only 80 percent of aggregate consumption. Although Bosworth et al. impute some missing consumption components, they ignore health care, as does Attanasio. This is a significant omission. Health care is a large and growing component of national consumption. Moreover, as medical consumption has grown as a share of output, so too has overall consumption. This suggests that medical consumption, or at least its method of finance, may play a key role in the decline in the U.S. rate of saving.

Even were all studies of personal saving in agreement, it would be hard to assess their implications for national saving. From a theoretical perspective, personal saving bears no necessary relationship to national saving. This point can be understood by considering the standard life-cycle model under certainty. According to this model, the appropriate measure of household saving is the propensity of households to consume out of the present value of their remaining lifetime resources. This propensity will be invariant to present-value neutral changes in the timing of after-tax income flows, each of which will produce a different value of personal saving.

For example, an increase in households' current Social Security taxes that is offset, in present value, by higher projected Social security benefits will leave their consumption and, thus, national saving unchanged, but lower their personal saving. The postwar period has witnessed enormous growth in Social Security and other government transfer programs. Hence, changes over time in U.S. personal saving rates could simply reflect the life-cycle pattern 
of these tax/transfer programs, rather than some underlying change in household consumption and saving behavior.

The problem with studying national saving via personal saving is actually deeper than this discussion suggests. The reason is that the tax and transfer labels of government receipts and expenditure programs are not unique (see, for example, Kotlikoff [1993]). Assuming agents are rational, the same fiscal policy can be relabeled in countless ways with no impact on economic outcomes, including national saving. But each relabeling will result in a different measure of personal saving. For example, suppose the U.S. government had historically labeled Social Security contributions as "loans" to the government rather than as "taxes" and current and past Social Security benefit payments as "repayment of past loans, plus an old-age tax" rather than as "transfer payments." 3 Doing so would have produced an entirely different postwar reported path of personal saving, but it would not have altered national saving, assuming rational consumption and saving behavior. In 1993, for example, the measured personal saving rate would have been almost three times larger than the rate the government actually reported!

Studies that focus directly on household consumption and, by implication, national saving are few and far between. Cutler et al. (1990) is one example. This study employs an infinite-horizon model to study the response of household consumption to demographic change. Its findings suggest that high rates of household consumption and low rates of national saving may

3 Such relabeling is not simply a hypothetical possibility. The socalled "privatization" of the Chilean social security system amounts, in large part, simply to relabeling workers' social security contributions as loans rather than as taxes. Under the Chilean "reform, "workers contribute to pension funds. But the pension funds turn around and lend most of these contributions to the government, which uses them to make benefit payments to current Social Security recipients. 
reflect households' projections of higher future per capita income levels arising from the aging of the U.S. population. However, there are two critical difficulties with this analysis. First, the assumed intergenerational altruism underlying the infinite-horizon model is strongly rejected by household and cohort panel data (see Altonji, Hayashi, and Kotlikoff [1992]; Abe1 and Kotlikoff [1994]; and Hayashi, Altonji, and Kotlikoff [1994]). Second, the study's results are highly sensitive to the assumption about the economy's initial position (that is, whether it is initially in a steady state.)

Boskin and Lau (1988a and 1988b) estimate an aggregate consumption function taking into account aggregation over different cohorts. Their results suggest that a decline in saving by generations born after the Great Depression is largely responsible for the postwar decline in U.S. saving--a finding at odds with those reported here. Boskin and Lau's methodology differs significantly from our approach, so it is hard to say precisely why the two studies reach such different conclusions.

III. The Postwar Decline in U.S. Saving--Some Stylized Facts

Table 1 reports average values of the net national saving rate for the 1950s, 1960s, 1970s, and 1980s, as well as the first four years of the 1990s. The net national saving rate is defined as $(Y-C-G) / Y$, where $Y$ refers to net national product, $C$ to household consumption, and $G$ to government spending (purchases of goods and services). The table also reports rates of government and household consumption out of output, $G / Y$ and $C / Y$. In addition, it reports our preferred measure of private-sector saving, which we call the household saving rate. It's defined as $(Y-G-C) /(Y-G)--$ the share saved of the output left over to the household sector after the government has consumed (that is, 
the share of $\mathrm{Y}-\mathrm{G}$ that is not consumed by the public). Unlike the personal saving rate, the household saving rate isn't affected by present-value neutral changes in the timing of income flows. Nor is it altered by pure changes in the labeling of government receipts and expenditures, assuming agents are rational and aren't deceived by the government's choice of words.

As Table 1 indicates, government spending is not responsible for reducing the rate of national saving. Indeed, the rate of government spending, G/Y, has declined since the 1970s. Furthermore, government spending in the 1990s has averaged just 21 percent of output-as low a rate as any observed in the five periods. The rate of household consumption spending, on the other hand, rose from 69.9 percent of output in the 1950 s to 76.5 percent in the early 1990s. This increased rate of household consumption was associated with a decline in the household saving rate from 11.5 percent in the 1950 s to 3.1 percent in the $1990 \mathrm{~s}$.

Table 2 considers the role of health-care spending in the growth of household spending. It shows that medical expenditures have increased from 3.9 percent of NNP in the $1950 \mathrm{~s}$ to 12.8 percent in the $1990 \mathrm{~s}$. In the $1950 \mathrm{~s}$ health-care spending represented less than 6 percent of household consumption. So far, in the 1990s, it has represented almost 17 percent. The increase in the rate of medical spending was associated with only a modest reduction in the rate of nonmedical spending. In the 1950s, nonmedical consumption averaged 66 percent of NNP. In the 1990s, it averaged 63.7 percent. Thus, although the rate of medical consumption rose by 8.9 percentage points between the 1950 s and $1990 \mathrm{~s}$, the rate of nonmedical consumption fell by only 2.3 percentage points. 


\section{Decomposing Changes in National Saving}

We adopt the life-cycle model under certainty as our framework for decomposing postwar changes in national saving. In so doing, we don't mean to belittle other determinants of saving, such as uncertainty and the desire to bequeath. Rather, we believe that this model is a useful place to begin investigating the decline in U.S. saving. We also suspect that the findings reported here will carry over to more realistic models of saving.

Our interest is in the net national saving rate, which, at time $t$, is given by

$$
\frac{S_{t}}{Y_{t}}=1-\frac{C_{t}}{Y_{t}}-\frac{G_{t}}{Y_{t}} \text {, }
$$

where $S_{t}$ stands for net national saving.

In the standard life-cycle model with certainty and homothetic preferences, each cohort's consumption is proportional to the present value of its remaining lifetime resources (resources for short). We denote the per capita resources of cohort age $i$ at time $t$ as $r_{i t}$. This is the sum of the cohort's per capita net wealth, $\mathrm{nw}_{\mathrm{it}}$, its per capita present value of future labor earnings (human wealth), $h w_{i t}$, its per capital present value of private and government employee pension benefits (their pension wealth), $\mathrm{pw}_{i t}$, less its per capita present value of future tax payments net of the per capita present value of future transfer payments received (their generational accounts), ga $_{\text {it. }}$

Since our empirical analysis attributes all consumption to adult cohorts age 18 through 100, we write aggregate consumption at time $t$ as the sum of consumption of individual cohorts ${ }^{4}$ age 18 through 100 , that is, as

4 Cohorts older than 100 years are grouped together with those age 100 . 


$$
C_{t}=\sum_{i=18}^{100} \alpha_{i t} r_{i t} P_{i t}
$$

where $i$ indexes age, $\alpha_{i t}$ stands for the average propensity to consume of $i$ year olds at time $t$, and $P_{i, t}$ represents the number of persons who are $i$ years old at time $t$. We note for future reference that $\alpha_{i t}=c_{i t} / r_{i t}$, where $c_{i t}$ is the average level of consumption of those age $i$ at time $t$.

Our goal is to decompose changes over time in the net national saving rate into changes in the rate of government spending, $G_{t} / Y_{t}$, and changes in determinants of the rate of household spending, $C_{t} / Y_{t}$. These determinants are clarified by expressing the rate of household spending as

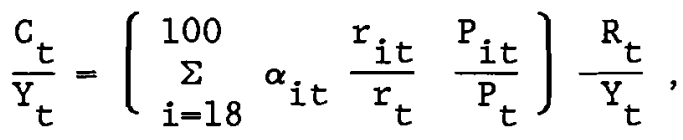

where $R_{t}$ stands for the time-t total value of resources of living generations (that is, $R_{t}=\Sigma_{i} r_{i t} P_{i t}$ ), $P_{t}$ stands for the total population at time $t$, and $r_{t}$ stands for the time-t resources per capita of living generations.

According to (3), changes over time in the rate of household consumption can be traced to changes over time in four factors: cohort-specific propensities to consume (the $\alpha_{i t} s$ ), the shape of the age-resource profile (the $r_{i t} / r_{t} s$ ), the age composition of the population (the $P_{i t} / P_{t} s$ ), and the resource-output ratio-the ratio of total resources of current generations to current output $\left(R_{t} / Y_{t}\right)$.

In our empirical analysis we compute the values of five factors-the above four plus government spending--for each of four time periods: 1960-61, 1972-73, 1984-86, and 1987-90. We then consider how the national saving rate in each of these periods would have differed had one of the five factors not 
taken its actual value, but had, instead, taken values observed in other periods.

This decomposition of changes in life-cycle saving into those due to changes in demographics, saving behavior, and age-resource profiles has a long tradition dating to Ando and Modigliani (1963). Their lessons bear repeating. First, increases in any cohort's propensity to consume will, all else being equal, raise the rate of aggregate household spending and lower national saving. Second, higher rates of population or real wage growth mean higher rates of national saving for the following simple reason: In the life-cycle model, the propensity to consume is predicted to rise with age. Since population and real wage growth raise the respective values of the $P_{i t} / P_{t}$ and $r_{i t} / r_{t}$ ratios for younger cohorts and lower them for older cohorts, such growth produces a reweighting of $\alpha_{i t} s$, which reduces the rate of household spending and raises the rate of national saving.

The final lesson is that redistribution across generations can alter national saving by altering the age-resource profile, the resource-output ratio, or both. Government tax/transfer policy can, of course, produce such redistribution. Consider government redistribution among living generationsspecifically, from the young to the old at time t--that leaves the resourceoutput ratio unchanged. Such redistribution is accomplished by raising the present value of taxes net of transfers of young generations (their generational accounts) and reducing the present value of taxes net of transfers of older generations while leaving unchanged the net tax burden facing current generations collectively. This policy lowers the values of the $r_{i t} / r_{t} s$ of the young and raises them for the old. This raises the weights applied to relatively high values of $\alpha_{i t}$ and reduces those applied to relatively low values, producing a higher rate of aggregate household spending. 
Next, consider redistribution from future to current generations that raises the resource-output ratio but leaves the age-resource profile unchanged. This can be accomplished by reducing the generational accounts of each current generation by just the amount needed to produce the same percentage increase in its remaining lifetime resources. This policy raises the rate of household spending by an amount that depends on the resource- and population-weighted economy-wide propensity to consume (the bracketed term in equation [3]).

\section{v. Data Construction and Sources}

To decompose changes across our four periods in national saving, we need the value for each period of the five factors mentioned earlier. Two of these factors-the rate of government spending and the age composition of the population--are readily available. This is not the case for the value of the $c_{i t} s$ or the $r_{i t} s$, both of which are needed to form the $\alpha_{i t s}$. The $r_{i t} s$ are also needed to form the age-resource profile and the resource-output ratio.

Our procedures for calculating the $c_{i t}$ and $r_{i t} s$ are described in detail in the Appendix. Briefly, we form these variables or their constituent components by using cross-section profiles and population data to distribute aggregate variables by age and sex. Our general method of distributing an aggregate variable in time $t$, say $z_{t}$, can be understood by considering the following equation:

(4) $z_{t}=z_{m 40 t} \sum_{i=18}^{100}\left(v_{m i t} P_{m i t}+v_{f i t} P_{f i t}\right)$.

In equation (4), $z_{m 40 t}$ stands for the average value of $Z$ of 40-year-old males at time $t, v_{\text {mit }}$ and $v_{\text {fit }}$ stand, respectively, for the ratios of average values 
of $\mathrm{Z}$ of males and females age $i$ at time $t$ to $z_{40 m t}$, and $P_{\text {mit }}$ and $P_{f i t}$ stand, respectively, for the populations of males and females age $i$ in year $t$. Given the value of $z_{t}$ from the National Income and Product Accounts (NIPA) or other sources, the relative age-sex profile of $z$ (the $v_{\text {mit }} s$ and $v_{f i t} s$ ) calculated from a cross-section survey, and the $P_{\text {mit }}$ s and $P_{\text {fit }} s$ calculated from population data, we can use equation (5) to solve for $z_{m 40 t}$. We can then multiply this value by $v_{\text {mit }}\left(v_{f i t}\right)$ to determine $z_{\text {mit }}\left(z_{f i t}\right)$-the average value of $z$ for males (females) age $i$ in year $t$. Finally, we can form a population-weighted average of $z_{\text {mit }}$ and $z_{\text {fit }}$ to produce an average value of $z$ for age group $i$ at time $t$.

In the case of the $c_{i t} s$, we use the 1961-62, 1972-73, 1984-86, and 19871990 Consumer Expenditure Surveys and the 1977 and 1987 National Medical Expenditure Surveys to form relative profiles of total consumption by age and sex. By total consumption, we mean all components of household consumption that are included in the NIPA aggregate, including medical care and imputed rent on owner-occupied housing. In the process of forming these profiles, we had to allocate CEX household expenditures to individual adult members in the household. In so doing, we first allocated expenditures to all members of the household, including children, and then allocated children's expenditures to parents residing with them. Certain allocations were quite obvious, such as children's clothing. In other cases, we adopted what we believe to be reasonable rules, which are described in the Appendix. The age-sex relative consumption profiles for the four periods derived in these calculations are used, together with period-specific Social Security counts of population by age and sex, to distribute NIPA values of aggregate household consumption in each of the four periods. 
Turning to the $r_{i t} s$, recall that these variables are the sums of annuitized and nonannuitized resources. We form each of the components of the $r_{i t}$ separately and then add them. By annuitized resources we mean the present values of future labor earnings (human wealth), Social Security benefits, private and government employee pension benefits, government healthcare benefits, welfare benefits and other government transfers, and, entering as negative annuities, the present values of future taxes. Taxes include labor and capital income taxes, indirect taxes, payroll taxes, and property and other taxes. Nonannuitized resources refers simply to holdings of net wealth.

The computation of cohorts' nonannuitized resources for the four periods involves distributing by age and sex each year's aggregate value of household net wealth and then averaging over the years defining the four periods. The computation of each annuitized resource component is more involved. First, for each year between 1960 and 1993, the national aggregate for a particular type of payment (or receipt) is distributed by age and sex according to the cross-section, age-sex relative profile that is applicable to that payment (or receipt). For example, aggregate 1965 Social Security benefits are distributed according to the age-sex relative profile for these benefits in 1965 . This yields estimates of the per capita amounts of the payment (or receipt) by age and sex for that year. The per capita annuity values for years after 1993 are estimated by either 1) distributing projected aggregate payments or receipts according to the latest available cross-section relative profile or 2) assuming that age- and sex-specific per capita values equal their respective values in 1993 or some later year, except for an adjustment for productivity growth. 
Second, for each generation in a given year $t$, the present value of all future per capita payments of a particular type (say, indirect tax payments) is computed by multiplying these future per capita payments by the generation's projected population in those years, discounting these values back to year $t$, and dividing the sum of the discounted values by the number of members of the generation alive in the base year. This method produces actuarially discounted present values of the particular receipt or payment for each generation alive in period $t$. We consider three pretax real discount rates:

6 percent, 8 percent (our base case), and 10 percent. 5

As an example of this method for calculating the different components of annuitized resources, consider our estimate of human wealth (HW). Our formula for human wealth in year $t$ of $\operatorname{sex} x$ born in year $k, \mathrm{HW}^{\mathrm{x}} t, k$, is

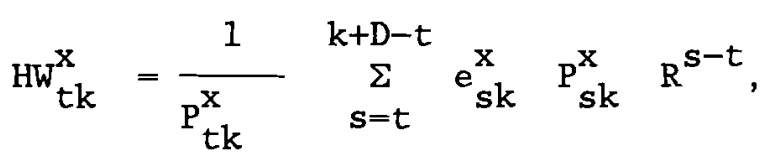

where $\mathrm{e}^{\mathrm{x}}$ sk stands for the average earnings in year $\mathrm{s}$ of a member of the generation born in year $k$ and of $\operatorname{sex} x ; P^{x}{ }_{s k}$ is the population in year $s$ of the same-sex-specific generation, $R=1 /(1+r)$, where $r$ is the rate of interest; and $D$ is the maximum age reached. The calculation of $e^{x}$ sk is given by

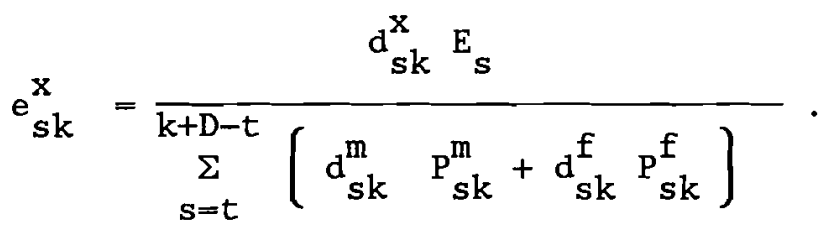

5 These rates bracket the pretax real rate of return observed, on average, between 1961 and 1992, where the rate of return in year $t$ is calculated as $\left[\left(\mathrm{NW}_{t}-\mathrm{L}_{t}-\mathrm{P}_{t}+\mathrm{C}_{t}+\mathrm{T}_{t}\right) / \mathrm{NW}_{t-1}\right]-1$ and $\mathrm{NW}_{t}$ is household net worth in period $t, L_{t}$ is aggregate labor income excluding contributions to private pension funds, $P_{t}$ is pension income including private pensions, government employee pensions, workers compensation and veterans benefits, $C_{t}$ is personal consumption expenditure, and $T_{t}$ is aggregate net tax payments. 
In (5) and (6), $E_{s}$ is aggregate labor earnings in year $s$ and $d^{x}{ }_{s k}$ is the ratio in year $s$ of the average earnings of the generation born in year $k$ of sex $x$, divided by the average earnings in year $s$ of our reference group-those who were age 40 in year $s$ (that is, those for whom $k=s-40$ ).

The construction of relative profiles by age and sex, $\mathrm{d}^{\mathrm{x}}{ }_{t k}$, is described in equations (7) and (8):

$$
j_{s, k}^{x}=\frac{\sum_{i=1}^{N_{k}^{x}} w_{s k i}^{x} j_{s k i}^{x}}{\sum_{i=1}^{N}{ }_{s k}^{x} w_{s k i}^{x}}
$$

and

$$
d_{s k}^{x}=\frac{j_{s k}^{x}}{j_{s, s-40}^{m}}
$$

In (7), $j^{\mathrm{x}}{ }_{s k}$ is the weighted average (across cohort members indexed by $i$ ) of labor income. $\mathrm{N}^{\mathrm{x}}{ }_{\mathrm{sk}}$ is the number of observations in year $s$ of individuals of sex $x$ born in year $k, j^{x}{ }_{s k i}$ is the wage and salary income of the $i^{\text {th }}$ individual of $\operatorname{sex} x$ in year $s$ who was born in year $k$, and $\mathrm{w}^{\mathrm{x}}{ }_{\mathrm{ski}}$ is the person weight of this observation. Equation (8) shows the calculation in year s of the average labor income of members of the generation belonging to sex $\mathrm{x}$ who were born in year $\mathrm{k}$, relative to that of contemporaneous 40-year-old males.

The national aggregates used in our calculations come from the National Income and Product Accounts (NIPA), the Federal Reserve System's Flow of Funds, The American Council of Life Insurance, the U.S. Census Bureau's Current Population Survey, and the Survey of Current Business. The sources for 
cross-section relative profiles are the CPS, the Survey of Income and Program Participation, the Consumer Expenditure Survey (CES), the Survey of Consumer Finances (SCF), the Social Security Administration's Annual Statistical Supplement, and the Health Care Financing Administration (HCFA). The computations also use the historic and projected population counts of the Social Security Administration.

\section{Findings}

\section{A. Looking at the Data}

Before decomposing past changes in the U.S. saving rate, it's worth considering some of the data we've constructed. We begin with figures 1 and 2 which show, respectively, relative profiles by age of total consumption and nonmedical consumption. Each figure contains profiles for the periods 1960$61,1972-73,1984-86$, and 1987-90. The choice of periods was based on the availability of CES data. For each period, the average consumption of 40year-olds is normalized to 1 .

The figures document a remarkable increase in the relative consumption of the elderly. This increase is more pronounced if medical care is included in the measure of consumption, but the increase in the relative consumption of nonmedical goods and services is also striking. Tables 3 and 4 examine some of the numbers underlying figures 1 and 2 . They report ratios of average levels of total as well as nonmedical consumption of 60-,70-, and 80-yearolds to the respective levels of 20-, 30-, and 40-year-olds for each of the four periods. According to the tables, 70-year-olds in 1960-61 consumed about 71 percent of the amount consumed by 30-year-olds in 1960-61, whereas their consumption now exceeds that of 30 -year-olds by 18 percent. In the case of nonmedical consumption, 70-year-olds consumed about 63 percent of the amount 
consumed by 30-year-olds in 1960-61, compared with 91 percent now. The increase in consumption by the elderly, relative to other ages, is equally dramatic.

The striking increase in the relative consumption of the elderly has coincided with an equally remarkable increase in their relative resources. Figure 3 depicts changes in the age distribution of resources (the $r_{i t} / r_{t} s$ ) across the four time periods. ${ }^{6}$ Table 5 presents the ratios of the average resources of persons aged 60,70 , and 80 years to those aged 20, 30, and 40 years. In 1960-61, the average resources of 70-year-olds were only 56 percent as large as those of 30-year-olds. In 1987-90, they were 85 percent as large. The resources of other older cohorts have also grown significantly relative to those of younger cohorts over the past three decades.

Figures 4 through 7 show the components of $r_{i t} / r_{t} s$ : the human wealth ratio, $h w_{i t} / r_{t}$, nonhuman wealth ratio, $\mathrm{nw}_{i t} / \mathrm{r}_{t}$, pension wealth ratio, $\mathrm{pw}_{i t} / \mathrm{r}_{t}$, and generational account ratio, $\mathrm{ga}_{i t} / \mathrm{r}_{t}$. Figure 4 indicates a sizable decline in the human wealth ratio for young cohorts. Indeed, this decline accounts for most of the overall decline in $r_{i t} / r_{t}$ for young cohorts. The reduction in the ratio of human wealth to resources at these ages is the result of a low projected rate of labor income growth compared to the 1960 s and early 1970s.7 Figure 5 shows profiles of $\mathrm{nw}_{i t} / \mathrm{r}_{t}$ for the four periods. Interestingly, although this ratio falls for all cohorts, it falls most precipitously for the

6 The kinks at age 80 in figure 3 reflect our method of imputing relative nonhuman wealth for individuals age 80 and above. The small number of observations at these ages in the Survey of Consumer Finances precludes forming separate estimates of average nonhuman wealth at these ages. Here, we assume that the relative nonhuman wealth of those 80 or older equals that of 80-year-olds of the same sex.

7 Note that our base-case calculations assume a 0.75 percent annual growth in labor productivity. 
oldest age groups. As figure 3 shows, the overall ratio $r_{i t} / r_{t}$ increased for almost all older cohorts, despite a steep decline in their nonhuman wealth ratio. Figure 6 presents the ratio of pension wealth to resources, $\mathrm{pw}_{i t} / \mathrm{r}_{\mathrm{t}}$, for each of the four periods. As indicated, cohorts of preretirement age experienced particularly rapid growth in pension wealth over the last three decades. The increase in $\mathrm{pw}_{i t} / \mathrm{r}_{\mathrm{t}}$ accounts for a sizable part of the increase in $r_{i t} / r_{t}$ for these cohorts.

Figure 7 shows changes over time in the ratios of generational accounts to resources. Note that all cohorts experienced declines in $\mathrm{ga}_{i t} / \mathrm{r}_{t} \mathrm{~s}$ between the early 1960s and late 1980s. However, the reductions are much larger for cohorts aged 55 and older. In 1960-61, for example, the present value of net transfers to 70-year-olds amounted to 4 percent of per capita resources. In the late 1980s, the corresponding figure was about 25 percent. Changes in generational accounts are clearly responsible for most of the rise in the relative resources of the elderly in the postwar period.

Figure 8 graphs age-specific consumption propensities in each of the four periods. In each period, the propensity to consume is roughly constant prior to about age 60 and then rises steadily. There is a local peak between ages 35 and 45 in the graphs that appears to reflect household expenditures on child rearing. Note that this local peak occurs at later ages through time-a result that is consistent with the trend of parents having children at older ages.

The most notable feature of figure 8 , however, is that it documents a very substantial increase over time in the consumption propensities of older Americans. Take 80-year-olds, for example, whose propensity to consume rose from 8.7 percent in 1960-61 to 12.7 percent in 1987-90. Interestingly, there is no corresponding increase in the consumption propensities of the young and 
middle-aged. As shown in table 6, these findings-that the consumption propensities of the older old have risen and that those of the young and middle-aged have remained relatively constant--are robust to different assumed values of the discount rate. At a discount rate of 3 percent, for example, 80-year-olds' consumption propensity rises from 8.5 percent in 1960-61 to 11.5 percent in 1987-90 (see figure 9). At a discount rate of 9 percent, it rises from 8.9 to 13.8 percent.

Finally, consider figure 10, which shows changes over the four periods in the age composition of the U.S. population. The figure indicates a small rise since the early 1960s in the share of the population over age 65 . It also indicates that there were relatively more adults in their twenties and thirties in the late 1980s than in the early 1960s, and relatively fewer adults in their forties and fifties.

\section{B. Decomposing Postwar Changes in U.S. Saving}

Tables 7-12 examine the effect on U.S. saving of changes in the five factors mentioned above: the age distribution of resources, the resourceoutput ratio, $\mathrm{R} / \mathrm{NNP}$, propensities to consume, the age distribution of the population, and the rate of government spending (G/NNP). Except tables 9 and 12, which consider the effects of changes in the age composition of the population and the rate of government spending, each table shows results for real discount rates of 3,6 , and 9 percent.

\section{Changes in the Age-Resource Distribution}

Consider first the middle panel of table 7, which incorporates our basecase 6 percent real discount rate. In this panel, as well as all the other panels in tables $7-12$, the numbers along the diagonal are the actual rates of 
U.S. net national saving that were observed in the periods being studied. The off-diagonal numbers indicate the saving rate that would have been observed in the row period had the saving factor in question (in this case, the age distribution of resources) taken the column period's value.

Take the first number in the last row, 5.12, as an example. This is the saving rate that, all else being equal, would have been observed in 1987-90 had the age-resource distribution been the same then as it was in 1960-61. Since 3.38 is the actual saving rate observed in 1987-90, we conclude that the saving rate for that period would have been 51 percent larger had the ageresource distribution of the late 1980s matched that of the early 1960s.

A comparison of 5.23 (the last number in the first row of the central panel of table 7) with 7.85, the actual 1960-61 saving rate, provides another way to assess the importance of the change in the age-resource distribution. It shows that the saving rate would have been 33 percent smaller if everything else had remained as it was in 1960-61 but the age-resource distribution had changed as it did over the three decades. That is, a change in the age resource distribution alone would have been sufficient to depress saving rates.

The corner values in each panel of table 7 indicate that the shifts in the age-resource distribution among living generations is an important factor in explaining the much lower actual rates of U.S. saving that occurred in the late 1980s than in the early 1960s. But, as figure 3 shows, these ageresource profile changes did not occur overnight. Indeed, the other values of table 7 show that the shifting age-resource distribution has been responsible for a steady decline in national saving. 


\section{Changes in Average Propensities to Consume}

Table 8 shows the effect on the national saving rate of changes over time in average propensities to consume. The last number in the first column of the middle panel (2.10) indicates that, other things being equal, the 1987-90 net national saving rate would have been 38 percent lower had 1987-90 consumption propensities equaled those of 1960-61. This decrease in the saving rate may seem surprising, given the much larger consumption propensities of elderly cohorts in 1987-90. The reason for the decline becomes clear on a closer look at figure 8: Except for cohorts in their early 40s, the consumption propensities of most younger cohorts are lower in the late 1980s than in the early 1960s. The slightly higher consumption propensities of younger cohorts in the 1960-61 period produce a substantial negative effect on the saving rate because there are many more young individuals in the population than there are older ones, and because the consumption propensities of older persons were much lower in 1960-61 than in 1987-90. The last number in the first row of table 8 (9.46) shows that a change in cohort consumption propensities alone would have led to higher saving rates in the late 1980 s.

The conclusion that the steep increases in older generations' propensities to consume are more than offset by the declines in those of younger generations is robust for lower discount rates but not for higher ones. A lower discount rate of 3 percent reduces the 1987-90 profile of consumption propensities by more than it lowers that for 1960-61, because the degree of annuitization of wealth is much greater, especially for older cohorts in the late 1980s. ${ }^{8}$ Hence, as a comparison of figures 8 and 9 indicates, using a 3 percent instead of a 6 percent discount rate produces a

8 See Auerbach et a1. (1994). 
larger decline in the profile for 1987-90 than for 1960-61. As a result, the saving rate is even lower if the 1960-61 consumption propensities profile is used in place of the 1987-90 profile. The reverse argument holds for a higher discount rate. Hence, at a 9 percent interest rate, the saving rate would have been larger had the 1960-61 consumption propensities prevailed in the 1987-90 period.

\section{Changes in the Population Distribution}

Table 9 shows the effect on U.S. saving rates of changes over time in the age composition of the population. As we have noted, had the 1960-61 age distribution of the population prevailed in 1987-90, the U.S. saving rate would have been 2.44 percent rather than 3.38 percent. This result can be understood by recalling that the propensity to consume rises with age and, as shown in figure 10, the age distribution of the early 1960s featured relatively more middle-aged Americans and relatively fewer younger Americans than did the age distribution of the late 1980s.

4. Changes in the Resources-Income Ratio

Table 10 shows the impact of changes over time in the ratio of resources to income. The last number in the first column of the middle panel (8.34) indicates that saving rates would have been two and a half times as large if the 1960-61 R/NNP ratio had prevailed in 1987-90. Table 11 reports this ratio and its components for the four periods and for the three discount rates. For the base case ( $r=6$ percent), R/NNP increased from 12.72 to 13.62 between 196061 and 1987-90. An increase in this ratio raises the rate of consumption out of income and reduces the net national saving rate. 
The decomposition of the change in R/NNP in table 11 shows that increases over time in the ratios of human and nonhuman wealth to net national product (HW/NNP and NHW/NNP, respectively) are not responsible for the increase in R/NNP. Rather, it is partially the increase in the ratio of pension wealth to income (PW/NNP), but primarily the decline in the ratio of aggregate generational accounts to income (GA/NNP), that causes the rise. In other words, the government's intergenerational redistribution of resources, particularly the redistribution from future to living generations, is primarily responsible for the increase in the resource-income ratio, which, in turn, appears to be the single most important cause of the decline in U.S. national saving.

\section{Changes in the Government Spending Rate}

Table 12 considers how changes in the government spending rate, G/NNP, have affected national saving. This rate fell slightly from 21.6 percent in 1960-61 to 21.2 percent in 1987-90. The numbers in the middle panel show that had G/NNP in 1987-90 taken on its 1960-61 value, the 1987-90 U.S. saving rate would have been 12 percent smaller; in other words, the rate of government spending in the late 1980 s is not responsible for the low rate of national saving during that period.

\section{The Case of No Annuity Markets}

The foregoing discussion assumes that individuals can convert future income flows into currently disposable resources at actuarially fair discount rates-that is, the pretax rate of interest plus the probability of death conditional on age. This is equivalent to assuming the existence of explicit or implicit actuarially fair annuity insurance. To investigate the robustness of the results to this assumption, we now consider the opposite assumption- 
that no annuity insurance is available. The appropriate rate for discounting future flows under this assumption is simply the pretax rate of interest.

Table 13 indicates that the no-annuity-insurance assumption does not materially affect the results of tables 7 through $12 .{ }^{9}$ Applying the 1960s' propensities to consume to the cohort-specific resource levels of the late 1980 s reduces the saving rate in the late 1980 s from 3.4 percent to 2.42 percent rather than to 2.10 percent as in the previous case. The effects on national saving of switching the age-resource distribution and the resourcesto-income ratio are almost identical to earlier cases: With the 1960-61 ageresource distribution, the saving rate would have increased from 3.4 percent to 5.07 percent instead of to 5.12 percent. Finally, using the 1960-61 resources-to-income ratio increases the saving rate from 3.4 percent to 8.09 percent instead of to 8.34 percent as earlier.

\section{Conclusion}

This paper traces the dramatic postwar decline in U.S. saving to one main cause: government redistribution from young and as yet unborn generations to older ones. Without this factor, the current U.S. rate of national saving would be at least thrice as large. The increase in the rate at which older generations consume their resources has been offset by the decline of younger generations' consumption propensities. However, the increase in the relative resources of older Americans has led to a remarkable increase in their relative consumption. Today's 70-year-olds are consuming, on average, roughly one-fifth more than are 30-year-olds. Were this the early 1960s, they'd be consuming only two-thirds as much. The increase in the relative consumption

9 All the results of table 13 use the base-case value of $r=6$ percent. 
of the elderly remains dramatic, even if one considers only nonmedical consumption.

The fact that propensities to consume are not systematically larger, indeed are smaller, for most young and middle-aged cohorts in the late 1980s than in the early 1960s indicates that "spendthrift" young and middle-aged Americans are not to blame for the decline in U.S. saving. This is not to say that young and middle-aged Americans are saving enough. Given the severe imbalance in long-run U.S. fiscal policy, they need to save significant sums simply to safeguard themselves against future tax increases or reductions in transfer payments (Auerbach and Kotlikoff, 1994).

Since there is every reason to believe that U.S. intergenerational redistribution will continue apace, at least through the turn of this century, there is little doubt that U.S. saving rates will remain extremely low or decline even further. Anemic U.S. saving rates will spell anemic rates of U.S. domestic investment, labor productivity growth, and real wage growth. This is the unfortunate legacy of the uncontrolled intergenerational redistribution that has been fueling ever higher rates of U.S. consumption. 
Appendix: Data Sources and Construction

\section{Labor Income}

Aggregate labor income between 1960 and 1993 is calculated as labor's share of NIPA-reported nationa1 income. For each of these years, 1abor's share of national income is calculated under the assumption that its share of proprietorship income is the same as its share of national income. 10 Relative profiles of labor income by age and sex are calculated for each year between 1963 and 1987 using that year's CPS data. The 1963 profile is used to distribute aggregate labor income for years prior to 1963, and the 1987 profile is applied for years after 1987. Per capita labor income for years beyond 1993 is projected under the assumption that, except for an adjustment for growth, cohorts of a given age and sex earn the same average labor income in future years as cohorts of that age and sex earned in 1993. For example, males who are age 50 in 1994 assumed to earn the same amount on average, apart from an adjustment for growth, as males who were age 50 in 1993. The growth adjustment is 1.2 percent per year. Thus, the projected average earnings of males aged 50 in, say, 1996 equals the corresponding 1993 average for males aged 50 , multiplied by $(1.012)^{3}$.

10 The share of labor income in national income is $\alpha$, where $\alpha$ satisfies $C$ $+\alpha \mathrm{PI}=\alpha \mathrm{NI}$. In this equation, $\mathrm{C}$ is compensation paid to employees less employer contributions to employee pension plans, PI is proprietorship income, and NI is national income. The calculated values of $\alpha$ are quite stable over the period 1960-1992, ranging between 0.76 and 0.82 . 


\section{Pension Benefits}

Pension benefits include private pension benefits, workers compensation, veterans benefits, and government employee pension benefits. Aggregate pension benefits for the years 1960-1988 are taken from Park (1992). Here, the NIPA estimates are used primarily because estimates based upon administrative reports are generally deemed more reliable than those based upon household surveys. The estimates for years after 1988 were derived by applying the average growth rate of real benefits between 1984 and 1988 to the 1988 figure. The aggregates for the other three types of benefits are taken from SCB.

The relative profiles for all four types of pensions are computed from the March CPS. This survey contains information on pension income from a variety of sources including company or union pensions, workers compensation, veterans benefits, and government employee pensions, and receipts from annuities and other regular contributions. For all categories retirement, disability, and survivor benefits are included. Separate profiles were obtained for each of the years between 1970 and 1992. The 1970 profile was used to distribute the aggregates in years prior to 1970 . For years after 1992 , it is assumed that real average pension benefits at a given age and sex equal their 1992 values adjusted for our assumed 1.2 percent rate of growth.

\section{Social Security Benefits}

Aggregate Social Security benefits between 1960 and 1993 are those reported in the NIPA. Between 1993 and 2030 we use the Office of Management and Budget's 
(OMB) projections (on a NIPA basis) of Social Security benefits. Aggregate Social Security 01d Age, Survivor, and Disability Insurance (OASDI) benefits after 2030 equal the 2030 aggregate adjusted for growth. The growth rates applied in this case are those embedded in a special Social Security Administration projection of total benefit payments for the years after 2030. This projection incorporates Social Security's intermediate economic and demographic assumptions with one exception: The productivity growth rate is assumed to equal 1.2 percent.

The SSASS reports average benefits by age and sex by type of benefit as well as the total number of recipients in each age-sex category. These data were used to form population-weighted per capita OASDI benefit profiles by age and sex. Relative profiles for OASDI benefits for each year from 1960 through 1990 were obtained from that year's SSASS. For years after 1990 we use the 1990 relative profile of Social Security benefits by age and sex.

\section{Medicare and Medicaid Benefits}

Aggregate Medicare and Medicaid payments from the inception of these programs through 1993 are reported by NIPA. OMB provided us with unpublished projections (on a NIPA basis) of aggregate Medicare payments for the years 1994 through 2030. In the case of Medicaid, we applied OMB's projected annual growth rates for grants in aid to state and local governments between 1994 and 2030 to the 1993 aggregate NIPA value of Medicaid. Beyond 2030, both Medicare and Medicaid payments are assumed to grow in accordance with demographic change and our assumed productivity growth rate. Relative profiles of Medicare and Medicaid benefits are based on HCFA data on average benefits by 
age and sex. In the case of Medicare, the data are available only by fiveyear age groups.

Unemployment Insurance, Aid to Families with Dependent Children, Food Stamps, and General Welfare Benefits

Aggregate values of these federal, state, and local transfers are reported by NIPA. State and local supplemental security income as well as transfers for employment and training are distributed according to the relative profile for AFDC. General welfare benefits include federal black-lung benefits, state general assistance, state energy assistance, education benefits, and other federal, state, and local transfers. The aggregate amount of earned incometax credit was distributed according to the relative profile for food stamps. Profiles for unemployment insurance, food stamps, AFDC, and general welfare are computed from the 1983 SIPP. These relative profiles were used to distribute their respective aggregate expenditures for all of the years between 1960 and 1993. For future years we assume that the age- and sexspecific values of each of these types of transfer payments keep pace with productivity growth.

\section{Labor Income Taxes}

Aggregate federal, state, and local income taxes for 1960 through 1993 are reported in NIPA. For 1993 through 2030 we use OMB's projections of federa1 income tax revenues. State and local income taxes for 1993 through 2030 are projected using $O M B^{\prime} s$ GDP forecast and assuming that the same ratio of state 
and local income taxes to GDP prevails between 1993 and 2030 as prevailed in 1993.

Aggregate labor income taxes in each year are calculated as the product of total federal, state, and local income taxes and labor's share of national income. We distribute aggregate labor income taxes based on the CPS profiles of labor income described above. After 2030 we assume that age- and sexspecific values of labor income taxes keep pace with productivity growth.

\section{Payro11 Taxes}

The NIPA reports aggregate values of payroll taxes from 1960 through 1993. The OMB provided us with projections of aggregate federal payroll taxes from 1994 through 2030. Aggregate state and local payroll taxes for 1994 through 2030 were calculated based on OMB's projection of GDP between 1994 and 2030 and the assumption that the 1993 ratio of state and local payroll taxes to GDP prevails through 2030. Aggregate payroll taxes in the years 1960-2030 are distributed by age and sex according to 1963 through 1992 CPS profiles of covered earnings (labor earnings subject to Social security payroll taxes). 11 Age- and sex-specific values of payroll taxes beyond 2030 are assumed to equal their 2030 values adjusted for growth.

\section{Excise and Sales Taxes}

11 Unfortunately, the data do not permit the calculation of separate profiles for state and local payroll taxes, which aren't necessarily subject to earnings ceilings. However, non-Social Security payroll taxes are a small fraction of the total (less than 30 percent), so the bias associated with profiles of earnings covered by Social Security is likely to be quite small. 
The NIPA is our source for aggregate excise-tax (including property tax) and sales-tax revenues from 1960 through 1993. For the period 1994-2030 we use OMB projections of federal excise- and sales-tax revenues. State and local excise- and sales-tax revenues between 1994 and 2030 are calculated using the 1993 ratio of these revenues to GDP and applying OMB's GDP forecasts through 2030 .

Relative age-sex profiles of excise and sales taxes were calculated from the 1960-61, 1972-73, 1984-86, and 1987-90 Consumer Expenditure Surveys (CEX). Separate profiles were constructed for tobacco, alcohol, and property taxes, and for all other sales and excise taxes. The 1960-61 profiles were used for years prior to 1966. The 1972-73 profiles were used for the years 1967 through 1978. The 1984-86 profiles were used for the years 1979 through 1986, and the 1987-90 profiles were used for 1987 and beyond. Age- and sex-specific values of sales and excise taxes beyond 2030 are assumed to equal the 2030 values adjusted for growth.

\section{Capital Income Taxes}

Aggregate capital income taxes between 1960 and 2030 are calculated as capital's share of national income, multiplied by actual or projected values of aggregate federal, state, and local income-tax revenues. Relative profiles for capital income taxes come from the 1962 and 1983 SCFs. These profiles are based upon weighted average net worth holdings by age and sex, where the weights applied are SCF person weights. This procedure could be applied only to individuals aged 80 or less because of the paucity of data for older indi- 
clevelandfed.org/research/workpaper/index.cfm

viduals. The profile of average net worth holdings by age and sex were smoothed and extrapolated through age 100 using a 4th order polynomial. Age- and sex-specific values of capital income taxes after 2030 are assumed to equal the 2030 values adjusted for growth.

Non Human Wealth

Age- and sex-specific values of nonhuman wealth (NHW) in each year between 1960 and 1993 are constructed by distributing by age and sex each of these years' levels of total private net wealth. Aggregate private net wealth for these years is reported in the FOF. ${ }^{12}$ The relative profiles of wealth holdings by age and sex are calculated by using data from the 1963 and 1983 SCF. The 1963 profiles are used for years prior to 1963 and the 1983 profile for years after 1983. The profiles for intermediate years are constructed by linearly interpolating between the 1963 and 1983 profiles.

Determining Average Consumption by Age and Sex

The data used for determining average consumption by age and sex for the years $1960-61,1972-73,1984-86$, and 1987-90 are the National Income and Product Accounts (NIPA), the 1960-61, 1972-73, and 1984-90 Consumer Expenditure Surveys (CEX), and the 1977 and 1987 National Medical Expenditure Surveys (NMES). Aggregate NIPA household consumption expenditure was allocated to adults based on four relative profiles of consumption by age and sex-one for

12 Our aggregates are net of the FOF's estimate of the value of residential structures, plant, and equipment owned by nonprofit institutions. 
the years 1960-61, one for the years 1972-73, one for the years 1984-86, and one for the years 1987-90.

To use the 1960-61 CEX, we first needed to impute particular demographic Information to households. The reason is that the 1960-61 CEX provides only general information about the ages and sexes of household members other than the head and spouse. Our imputation used a statistical match with the 1960 Decennial Census. Specifically, we sorted the Census data by a set of variables that are also available in the CEX. These include demographic variables, such as the number of children under age 18 and the ages and sexes of the household head and spouse, household income, the sex and marital status of the head, an urban versus rural indicator, region, and housing tenure. For each 1960-61 CEX household with members other than the head and spouse, we then randomly selected a Census household from the set of Census households with the same matching data. The ages and sexes of the Census household members other than the head and spouse were then attributed to the CEX household.

Each of the four relative age-sex consumption profiles was formed in a similar manner. First, we divided the NIPA consumption aggregates into 35 separate components. For most of these components, such as clothing, there are corresponding data in the CEX that can be used to distribute the aggregate values. For three other components, imputed rent, financial services, and expenditures by charitable institutions, there is no corresponding direct measure in the CEX, but there are other CEX variables (e.g., house value in the case of imputed rent) that can be used for distribution purposes. This is 
not the case for the health-care component of aggregate NIPA consumption, so we use the NMES to distribute health care.

The second step in forming age-sex consumption profiles involved benchmarking the distribution data to the relevant component of the NIPA consumption aggregate. Take NIPA clothing, for example. For this component, we divided NIPA clothing by the total CEX clothing expenditure, where the total was computed using the CEX household weights. The resulting ratio was used to rescale the clothing expenditure of each household in the CEX. Separate rescaling of clothing was done for each of CEX surveys used in the study based on the contemporaneous NIPA value of clothing. This procedure was used to rescale the CEX data for each of the NIPA components for which there are also direct CEX measures.

In the case of the NIPA aggregate for imputed rent, we calculated the ratio of NIPA aggregate imputed rent to total CEX reported house values, again computing the total using the CEX household weights. We then multiplied each household's reported house value by this ratio to produce a NIPA-benchmarked estimate of the household's imputed rent. The same procedure was used in the case of financial services, expenditures by charitable institutions, clothing provided by the military, food produced and consumed on farms, and net foreign remittances except that, instead of house value, we used, respectively, checking plus saving accounts, charitable contributions, number of household members in the military, a dummy variable equal to 1 if the household owned a farm and 0 otherwise, and total other consumption. 
In the case of health-care expenditures, we benchmarked the NMES data using NIPA's five broad components: physician's services, hospital services, private health insurance, prescriptions, and other medical. Specifically, we formed the ratio of each of these components to the corresponding NMES totals (based on the NMES population weights) and then rescaled the NMES data based on these ratios. We used the 1977 NMES for the years 1960 and 1961 as well as 1972 and 1973, and the 1987 NMES for the years 1984 through 1990.

In the third step, we allocated our rescaled (NIPA-benchmarked) actual or imputed CEX data to individuals within the CEX household. (This was not necessary for the NMES, which takes the individual as the unit of observation.) For certain types of expenditures, the method of allocation was fairly clear. For example, boys' clothing expenditures was divided evenly among the household's male children, and pipe tobacco was divided evenly among the household's adult males. For other types of expenditures, we developed particular rules. Housing expenditures, including imputed rent, was allocated evenly to the head and spouse. And food, vacations, and other not readily allocable expenditure items, were divided evenly among the household's adult equivalents, where each adult was given an equivalency factor of 1 and each child under 18 was given a factor that increased linearly from .3 for newborns to 1 for 18-year-olds.

The fourth step entailed using the NIPA-benchmarked NMES data to calculate age- and sex-specific weighted average values of each of the five different types of health expenditures. These values were then attributed to individual members of the CEX households based on their ages and sexes. In this step we also allocated to individual members of the CEX households, based on their 
ages and sexes, average values of privately paid educational expenditures. These average values were determined by calculating average elementary and secondary school expenditures per child age 5 through 18 and average college expenditures per person age 18 through 24.

In the fifth step, we reallocated all of the CEX children's expenditures, including their imputed health expenditures, evenly to the head and spouse. We then combined these NIPA-benchmarked, CEX actual or imputed data for particular years (1960 and 1961, 1972 and 1973, 1984-1986, and 1987-1990) to form the ratios of the average value over these years of total expenditures of adults (those age 18 and older) of a particular age and sex to that of $40-$ year-old males. This provided our four age-sex relative consumption profiles.

We used our four age-sex relative consumption profiles and our age- and sexspecific population data to allocate total NIPA consumption over the four periods by age and sex. This procedure may appear to represent an unnecessary second round of benchmarking of aggregate NIPA consumption, but in so doing we assure ourselves that our final calculated values of average consumption by age and sex are consistent with the Census population data used to calculate age- and sex-specific values of average remaining lifetime resources. In particular, they avoid under- or overestimates of average age- and sexspecific consumption that would arise if the CEX household weights were systematically too high or too low. 


\section{References}

Abe1, Andrew and Laurence J. Kotlikoff, "Intergenerational Altruism and the Effectiveness of Fiscal Policy -- New Tests Based on Cohort Data," in Savings and Bequests, Toshiaki Tachibanaki, ed., Ann Arbor, Michigan: The University of Michigan Press, 1994, pp. 167-96.

Altonji, Joseph, Fumio Hayashi, and Laurence J. Kotlikoff, "Is the Extended Family Altruistically Linked? New Tests Based on Micro Data," American Economic Review, December 1992, pp. 1177-98.

Ando, Albert and Franco Modigliani, "The 'Life Cycle' Hypothesis of Saving: Aggregate Implications and Tests," American Economic Review, vol. 53, no. 1, 1963, pp. 55-84.

Attanasio, Orazio P., "A Cohort Analysis of Saving Behavior by U.S. Households," NBER working paper no. 4454, September 1993.

Auerbach, Alan J., Jagadeesh Gokhale, Laurence J. Kotlikoff, John Sabelhaus and David N. Weil, "The Annuitization of Americans' Resources: A Cohort Analysis," Federal Reserve Bank of Cleveland Working Paper No. 9413, November 1994.

Auerbach, Alan J. and Laurence J. Kotlikoff, "The U.S.' Fiscal and Saving Crises and Their Implications for the Baby Boom Generation, "forthcoming in Retirement in the 21st Century: Ready or Not?, Employee Benefit Research Institute, 1994.

Boskin, Michael J. and Lawrence J. Lau, "An Analysis of Postwar U.S. Consumption and Saving: Part I, The Model and Aggregation, " NBER Working Paper No. 2605, June 1988a.

Boskin, Michael J. and Lawrence J. Lau, "An Analysis of Postwar U.S. Consumption and Saving: Part II, Empirical Results," NBER Working Paper No. 2606, June $1988 \mathrm{~b}$.

Bosworth, Barry, Gary Burtless, and John Sabelhaus, "The Decline in Saving: Some Microeconomic Evidence," Brookings Papers on Economic Activity, vo1. 1, 1991, pp. 183-241.

Cutler, David M., James M. Poterba, Louise M. Sheiner, and Lawrence H. Summers, "An Aging Society: Opportunity or Challenge?" Brookings Papers on Economic Activity, 1990 , pp. 1-73.

Hayashi, Fumio, Joseph Altonji, and Laurence J. Kotlikoff, "Risk Sharing across and within American Families," revised mimeo 1994.

Kotlikoff, Laurence J., "From Deficit Delusion to the Fiscal Balance RuleLooking for an Economically Meaningful Way to Assess Fiscal Policy, Journal of Economics, Supplement 7, 1993, pp. 17-41. 
clevelandfed.org/research/workpaper/index.cfm

Park, Thae S. "Total Private Pension Benefit Payments, 1950-88" in Trends in Pensions 1992, U.S. Department of Labor, Pension and Welfare Benefits Administration, 1992 .

Summers, Lawrence H. and Chris Carro11, "Why Is U.S. National Saving So Low?" Brookings Papers on Economic Activity, vo1. 2, 1987, pp. 607-635. 
Table 1

Saving and Spending Rates

$\begin{array}{lcccc}\text { Period } & \begin{array}{c}\text { Net National } \\ \text { Saving } \\ \text { Rate } \\ (\mathrm{Y}-\mathrm{C}-\mathrm{G}) / \mathrm{Y}\end{array} & \begin{array}{c}\text { Government } \\ \text { Spending } \\ \text { Rate } \\ \mathrm{G} / \mathrm{Y}\end{array} & \begin{array}{c}\text { Household } \\ \text { Consumption } \\ \text { Rate } \\ \mathrm{C} / \mathrm{Y}\end{array} & \begin{array}{c}\text { Household } \\ \text { Saving } \\ \text { Rate }\end{array} \\ 1950-59 & .091 & .210 & .699 & \underline{(Y-G-C) /(Y-G)} \\ 1960-69 & .091 & .221 & .688 & .115 \\ 1970-79 & .085 & .214 & .701 & .117 \\ 1980-89 & .047 & .213 & .740 & .059 \\ 1990-93 & .025 & .209 & .766 & .032\end{array}$

Source: Authors' calculations based on National Income and Product Accounts. 
Table 2

The Growth of Household and Medical Consumption

$\begin{array}{cc}\text { Rate of } & \text { Rate of } \\ \text { Household } & \text { Medical } \\ \text { Consumption } & \text { Consumption }\end{array}$

$\begin{array}{lll}\text { Period } & \underline{\mathrm{C} / \mathrm{Y}} & \underline{\mathrm{M} / \mathrm{Y}} \\ 1950-59 & .699 & .039 \\ 1960-69 & .688 & .052 \\ 1970-79 & .701 & .073 \\ 1980-89 & .740 & .101 \\ 1990-93 & .766 & .128\end{array}$

Source: Authors' calculations based on National Income and Product Accounts. 
Table 3

Consumption of the Elderly Relative to the Young

Comparison

Age 60/Age 20

Age 70/Age 20

Age $80 /$ Age 20

Age 60/Age 30

Age 70/Age 30

Age $80 /$ Age 30

Age $60 /$ Age 40

Age 70/Age 40

Age $80 /$ Age 40

\section{$\underline{1960-61}$}

1.17

0.97

0.89

0.86

0.71

0.65

0.77

0.64

0.58 $\underline{1972-73}$

1.37

1.21

1.16

0.93

0.82

0.79

0.83

0.73

0.70 $\underline{1984-86}$

1.58

1.56

1.61

1.09

1.07

1.11

0.87

0.86

0.89 $\underline{1987-90}$

1.59

1.64

1.60

1.15

1.18

1.16

0.91

0.94

0.92

Source: Authors' calculations. 
Table 4

Nonmedical Consumption of the Elderly Relative to the Young

$\begin{array}{lcccc}\text { Comparison } & \underline{1960-61} & \underline{1972-73} & \underline{1984-86} & \underline{1987-90} \\ \text { Age 60/Age 20 } & 1.11 & 1.28 & 1.43 & 1.42 \\ \text { Age 70/Age 20 } & 0.86 & 1.04 & 1.22 & 1.28 \\ \text { Age 80/Age 20 } & 0.75 & 0.91 & 1.16 & 1.11 \\ \text { Age 60/Age 30 } & & & & \\ \text { Age 70/Age 30 } & 0.81 & 0.86 & 0.97 & 1.02 \\ \text { Age 80/Age 30 } & 0.63 & 0.70 & 0.83 & 0.91 \\ \text { Age 60/Age 40 } & 0.55 & 0.61 & 0.78 & 0.80 \\ \text { Age 70/Age 40 } & 0.73 & 0.78 & 0.77 & 0.80 \\ \text { Age 80/Age 40 } & 0.57 & 0.63 & 0.66 & 0.72 \\ \end{array}$

Source: Authors' calculations. 
Table 5

Resources of the Elderly Relative to the Young ( $r=6$ percent)

\begin{tabular}{|c|c|c|c|c|c|c|}
\hline Comp & arison & & $1960-61$ & $1972-73$ & $1984-86$ & $\underline{1987-90}$ \\
\hline Age & 60/Age & 20 & 0.80 & 1.02 & 1.18 & 1.22 \\
\hline Age & 70/Age & 20 & 0.60 & 0.79 & 0.97 & 1.01 \\
\hline Age & $80 /$ Age & 20 & 0.43 & 0.48 & 0.50 & 0.54 \\
\hline Age & 60/Age & 30 & 0.75 & 0.86 & 0.99 & 1.02 \\
\hline Age & 70/Age & 30 & 0.56 & 0.67 & 0.82 & 0.85 \\
\hline Age & 80/Age & 30 & 0.40 & 0.41 & 0.42 & 0.45 \\
\hline Age & 60/Age & 40 & 0.72 & 0.84 & 0.90 & 0.95 \\
\hline Age & 70/Age & 40 & 0.54 & 0.65 & 0.75 & 0.79 \\
\hline Age & 80/Age & 40 & 0.39 & 0.40 & 0.39 & 0.42 \\
\hline
\end{tabular}

Source: Authors' calculations. 
Table 6

Propensities to Consume at Selected Ages and Discount Rates

Age

$\underline{1960-61} \underline{1972-73} \quad \underline{1984-86}$

$\underline{1987-90}$

$r=3$ percent

$\begin{array}{rrrrr}20 & 2.2 & 2.3 & 2.0 & 2.1 \\ 30 & 3.3 & 3.4 & 2.9 & 2.9 \\ 40 & 4.1 & 4.1 & 3.7 & 3.9 \\ 50 & 4.6 & 4.4 & 4.0 & 4.0 \\ 60 & 5.4 & 5.1 & 4.4 & 4.5 \\ 70 & 6.4 & 6.2 & 5.7 & 6.0 \\ 80 & 8.5 & 10.0 & 11.8 & 11.5\end{array}$

$r=6$ percent

$\begin{array}{rrrrr}20 & 4.3 & 4.5 & 4.0 & 4.3 \\ 30 & 5.4 & 5.6 & 4.9 & 5.0 \\ 40 & 5.8 & 6.0 & 5.6 & 5.8 \\ 50 & 5.8 & 5.7 & 5.4 & 5.5 \\ 60 & 6.2 & 6.0 & 5.4 & 5.6 \\ 70 & 6.8 & 6.8 & 6.5 & 6.9 \\ 80 & 8.7 & 10.6 & 12.9 & 12.7\end{array}$

$\mathbf{r}=9$ percent

$\begin{array}{rrrrr}20 & 6.7 & 7.1 & 6.6 & 7.0 \\ 30 & 7.5 & 7.8 & 7.0 & 7.1 \\ 40 & 7.3 & 7.7 & 7.3 & 7.6 \\ 50 & 6.7 & 6.8 & 6.6 & 6.8 \\ 60 & 6.7 & 6.7 & 6.3 & 6.5 \\ 70 & 7.2 & 7.3 & 7.1 & 7.6 \\ 80 & 8.9 & 11.2 & 14.0 & 13.8\end{array}$

Source: Authors' calculations. 


\section{Table 7}

The Impact of the Changing Age-Resource Distribution on the Net National Saving Rate

\begin{tabular}{lrrrr} 
& \multicolumn{3}{c}{ resource distribution in period } \\
\cline { 2 - 4 } Period & $\underline{1960-61}$ & $\underline{1972-73}$ & $\underline{1984-86}$ & $\underline{1987-90}$ \\
$\mathbf{r}=3$ percent & & & & \\
$1960-61$ & & & & \\
$1972-73$ & 1.85 & 6.05 & 4.64 & 4.05 \\
$1984-86$ & 6.38 & 9.87 & 8.77 & 8.15 \\
$1987-90$ & 5.97 & 4.32 & 4.51 & 3.84 \\
& & & 4.04 & 3.38 \\
$\mathbf{r}=6$ percent & & & & \\
$1960-61$ & 7.85 & 6.19 & 5.27 & 5.23 \\
$1972-73$ & 11.13 & 9.87 & 9.22 & 9.13 \\
$1984-86$ & 6.05 & 4.93 & 4.51 & 4.38 \\
$1987-90$ & 5.12 & 3.97 & 3.51 & 3.38 \\
$\mathbf{r}=9$ percent & & & & \\
$1960-61$ & & & & \\
$1972-73$ & 7.85 & 6.24 & 5.56 & 5.86 \\
$1984-86$ & 11.14 & 9.87 & 9.45 & 9.67 \\
$1987-90$ & 5.92 & 4.73 & 4.51 & 4.70 \\
& 4.68 & 3.47 & 3.19 & 3.38
\end{tabular}

Source: Authors' calculations. 
Table 8

The Impact of Changing Propensities to Consume on the Net National Saving Rate

Period

$\underline{1960-61} \underline{1972-73} \quad \underline{1984-86} \quad \underline{1987-90}$

$r=3$ percent

1960-61

1972-73

7.85

7.49

14.06

13.29

$1984-86$

10.14

9.87

16.09

15.25

$-2.33$

$-2.82$

4.51

3.63

1987-90

$-2.36$

$-2.96$

4.24

3.38

$r=6$ percent

1960-61

1972-73

1984-86

7.85

11.84

1.76

2.10

5.71

10.57

14.28

4.51

4.57

9.46

9.87

$-0.62$

$-0.40$

3.29

1987-90

$r=9$ percent

$1960-61$
$1972-73$
$1984-86$
$1987-90$

7.85

4.59

7.96

6.55

12.86

9.87

12.79

11.36

4.52

1.09

4.51

3.02

5.13

1.58

4.84

3. 38

Source: Authors' calculations. 
Table 9

The Impact of Changing Population-Age Distribution

on the Net National Saving Rate

population-age distribution in period

\section{Period}

$\underline{1960-61} \underline{1972-73} \quad \underline{1984-86} \quad \underline{1987-90}$

1960-61

7.85

9.60

9.01

8.57

$1972-73$

7.97

9.87

9.23

8.69

1984-86

2.93

4.89

4.51

3.85

1987-90

2.44

4.24

4.01

3. 38

Source: Authors' calculations. 
Table 10

The Impact of the Resources-to-Income Ratio

on the Net National Saving Rate

Period

$\underline{1960-61} \underline{1972-73} \quad \underline{1984-86} \quad \underline{1987-90}$

$r$ - 3 percent

1960-61

$1972-73$

$1984-86$

1987-90

7.85

9.60

$-1.31$

$-1.04$

$-0.44$

8.13

9.87

13.02

14.64

4.51

$-0.17$

11.32

12.99

2.55

5.32

3.38

$r=6$ percent

1960-61

1972-73

1984-86

1987-90

\subsection{5}

6.42

11.22

9.87

2.27

2.89

9.94

13.22

0.70

1.34

8.34

11.70

4.51

5.11

2.76

3.38

$r=9$ percent

$\begin{array}{rrrrr}1960-61 & 7.85 & 12.22 & 4.84 & 5.39 \\ 1972-73 & 5.33 & 9.87 & 2.20 & 2.77 \\ 1984-86 & 7.54 & 11.94 & 4.51 & 5.06 \\ 1987-90 & 5.93 & 10.44 & 2.81 & 3.38\end{array}$

Source: Authors' calculations. 
Table 11

Decomposing Changes in $\mathrm{R} / \mathrm{NNP}^{\mathrm{a}}$

$r=3$ percent

$\underline{1960-61} \underline{1972-73} \quad \underline{1984-86} \quad \underline{1987-90}$

$\mathrm{R} / \mathrm{NNP}=$

$\mathrm{HW} / \mathrm{NNP}=$

NHW/NNP =

$\mathrm{PW} / \mathrm{NNP}=$

GA/NNP =

$r=6$ percent

$\mathrm{R} / \mathrm{NNP}=$

$\mathrm{HW} / \mathrm{NNP}=$

NHW/NNP =

$\mathrm{PW} / \mathrm{NNP}=$

$\mathrm{GA} / \mathrm{NNP}=$

$r=9$ percent

$\mathrm{R} / \mathrm{NNP}=$

$\mathrm{HW} / \mathrm{NNP}=$

NHW/NNP =

$\mathrm{PW} / \mathrm{NNP}=$

$\mathrm{GA} / \mathrm{NNP}=$
18.13

15.02

3.20

2.28

2.37

3.59

12.72

11.57

3.69

0.97

3.51

10.04

8.77

3.69

0.55

2.97
21.01

16.88

3.21

2.87

1.95

20.78

16.39

3.18

2.86

1.65

$a_{\mathrm{R} / \mathrm{NNP}}=[\mathrm{HW}+\mathrm{NHW}+\mathrm{PW}-\mathrm{GA}] / \mathrm{NNP}$ where $\mathrm{NNP}=$ net national product, $\mathrm{R}=$ total resources, $\mathrm{HW}=$ human wealth, $\mathrm{NHW}=$ nonhuman wealth, $\mathrm{PW}=$ pension wealth, and GA=generational account.

Source: Authors' calculations. 
Table 12

The Impact of the Rate of Government Spending

on the Net Nationa1 Saving Rate

\section{$\underline{\text { Period }}$}

1960-61

$1972-73$

1984-86

$1987-90$

$$
\mathrm{G} / \mathrm{Y}=
$$

government spending rate in period

$\underline{1960-61} \underline{1972-73} \quad \underline{1984-86} \quad \underline{1987-90}$

7.85

8.16

9.87

4.64

8.03

9.74

8.27

4.33

3.27

4.51

9.98

2.96

3.14

4.75

3.38

21.59

21.28

21.41

21.17

Source: Authors' calculations. 
Table 13:

Changes in the Net National Saving Rate:

The Case of No Annuity Insurance ( $r=6$ percent)

\begin{tabular}{|c|c|c|c|c|}
\hline \multirow[b]{2}{*}{ Period } & \multicolumn{4}{|c|}{ resource distribution in period } \\
\hline & 1960-61 & $1972-73$ & $1984-86$ & 1987-90 \\
\hline $\begin{array}{l}1960-61 \\
1972-73 \\
1984-86 \\
1987-90\end{array}$ & $\begin{array}{r}7.85 \\
11.13 \\
6.25 \\
5.07\end{array}$ & $\begin{array}{l}6.28 \\
9.87 \\
5.08 \\
3.87\end{array}$ & $\begin{array}{l}5.42 \\
9.24 \\
4.51 \\
3.25\end{array}$ & $\begin{array}{l}5.61 \\
9.38 \\
4.64 \\
3.38\end{array}$ \\
\hline
\end{tabular}

Impact of Changing Consumption Propensities

propensities to consume in period

\begin{tabular}{llll}
\hline $1960-61$ & $1972-73$ & $1984-86$ & $1987-90$
\end{tabular}

$\begin{array}{rrrrr}1960-61 & 7.85 & 5.50 & 10.19 & 8.71 \\ 1972-73 & 11.84 & 9.87 & 14.17 & 12.69 \\ 1984-86 & 1.85 & -0.56 & 4.51 & 2.96 \\ 1987-90 & 2.42 & -0.06 & 4.89 & 3.38\end{array}$

Impact of Changing Resources-to-Income Ratio (R/NNP)

$\mathrm{R} / \mathrm{NNP}$ in period

\begin{tabular}{llll}
\hline $1960-61$ & $1972-73$ & $1984-86$ & $1987-90$
\end{tabular}

$\begin{array}{rrrrr}1960-61 & 7.85 & 11.27 & 2.47 & 3.16 \\ 1972-73 & 6.37 & 9.87 & 0.85 & 1.56 \\ 1984-86 & 9.77 & 13.09 & 4.51 & 5.19 \\ 1987-90 & 8.09 & 11.51 & 2.69 & 3.38\end{array}$

NOTE ${ }^{a}$

$\begin{array}{lrrrr}\mathrm{R} / \mathrm{NNP}= & 15.25 & 14.51 & 16.41 & 16.26 \\ \mathrm{HW} / \mathrm{NNP}= & 12.11 & 10.75 & 11.79 & 11.47 \\ \text { NHW/NNP }= & 3.69 & 3.20 & 3.21 & 3.18 \\ \mathrm{PW} / \mathrm{NNP}= & 1.56 & 1.68 & 2.06 & 2.05 \\ \mathrm{GA} / \mathrm{NNP}= & 2.12 & 1.12 & 0.65 & 0.43\end{array}$

${ }^{\mathrm{a} S e e}$ footnotes to table 11 for definitions.

Source: Authors' calculations. 

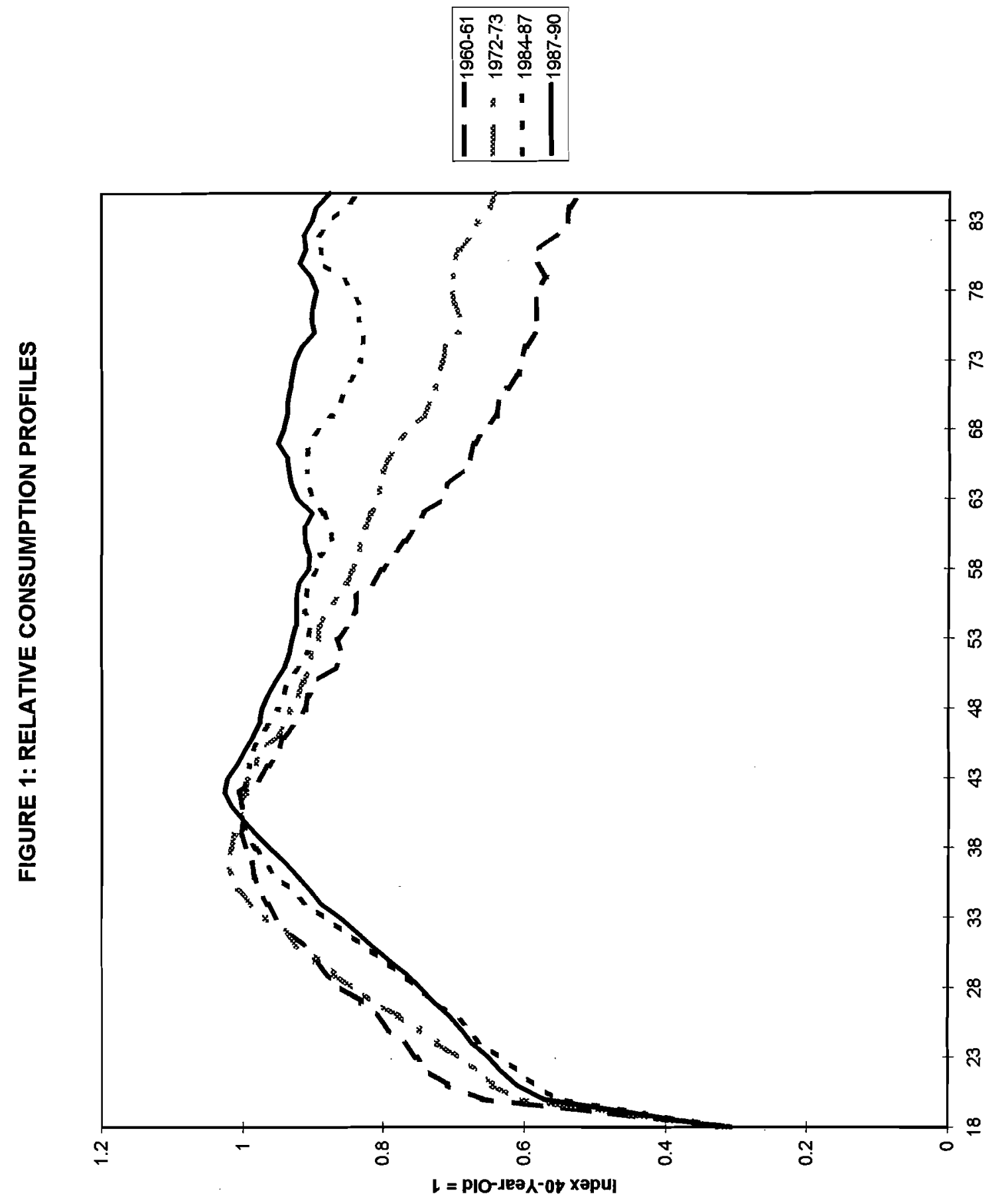


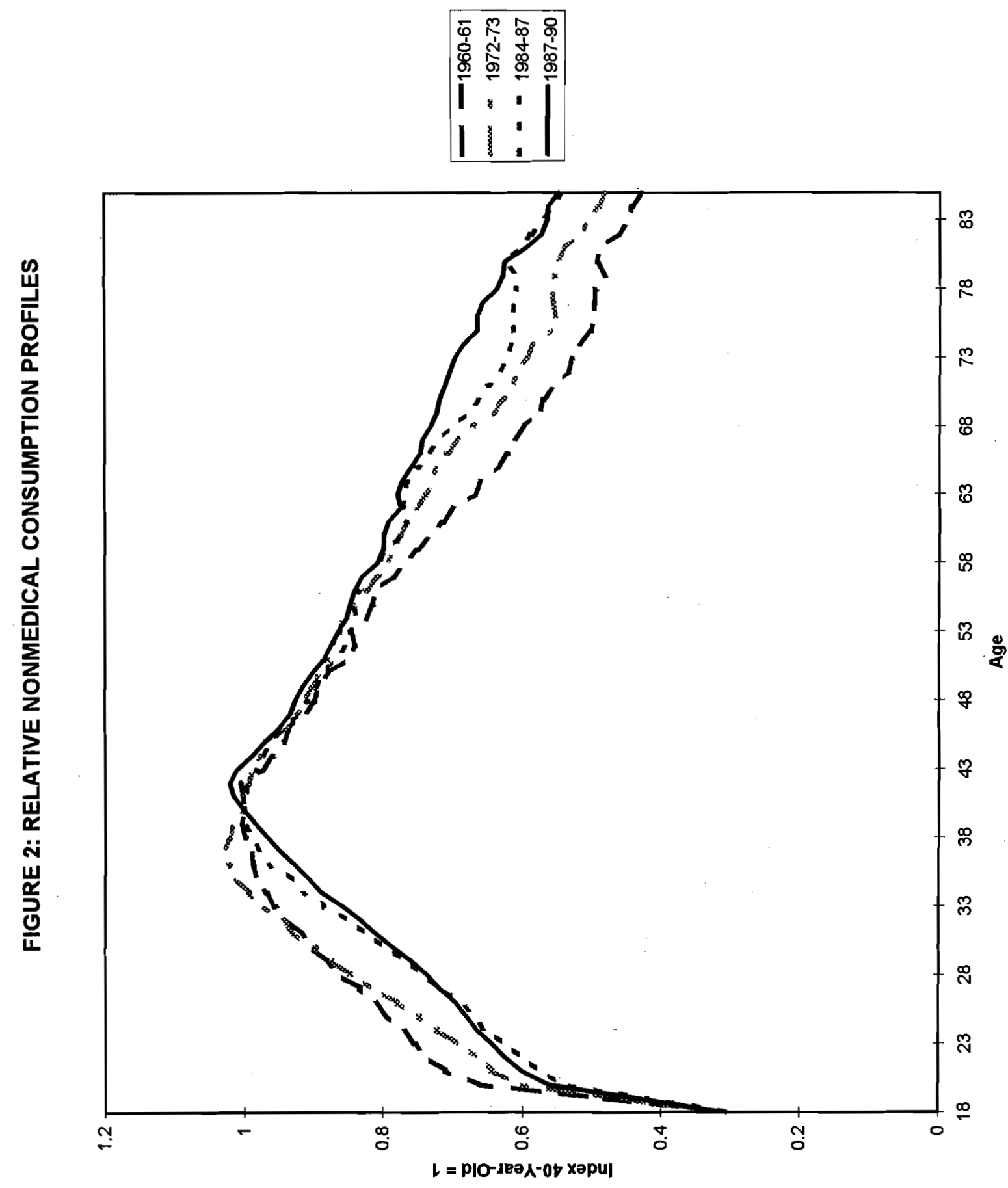


FIGURE 3: COHORT RESOURCES PER CAPITA / PER CAPITA RESOURCES

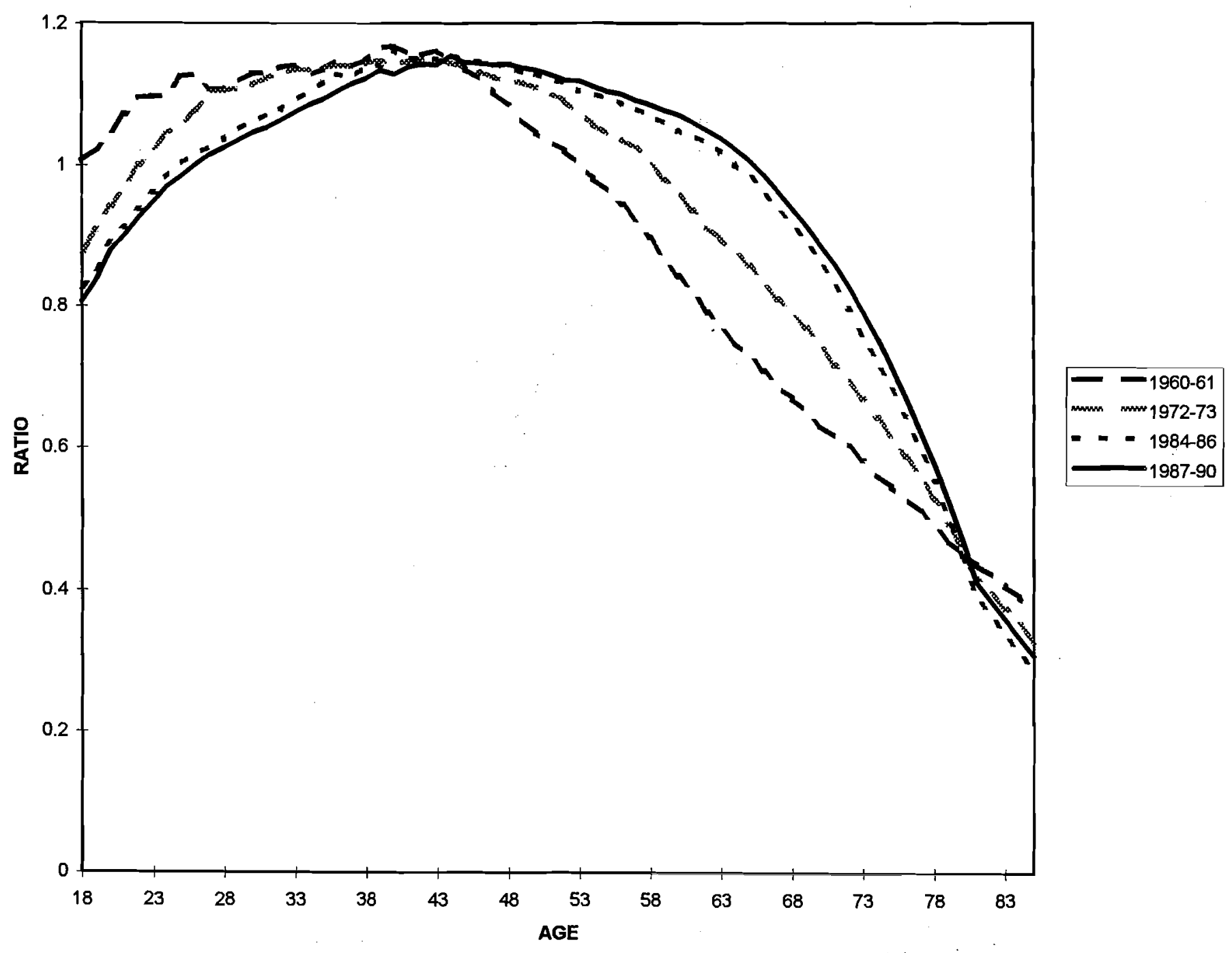




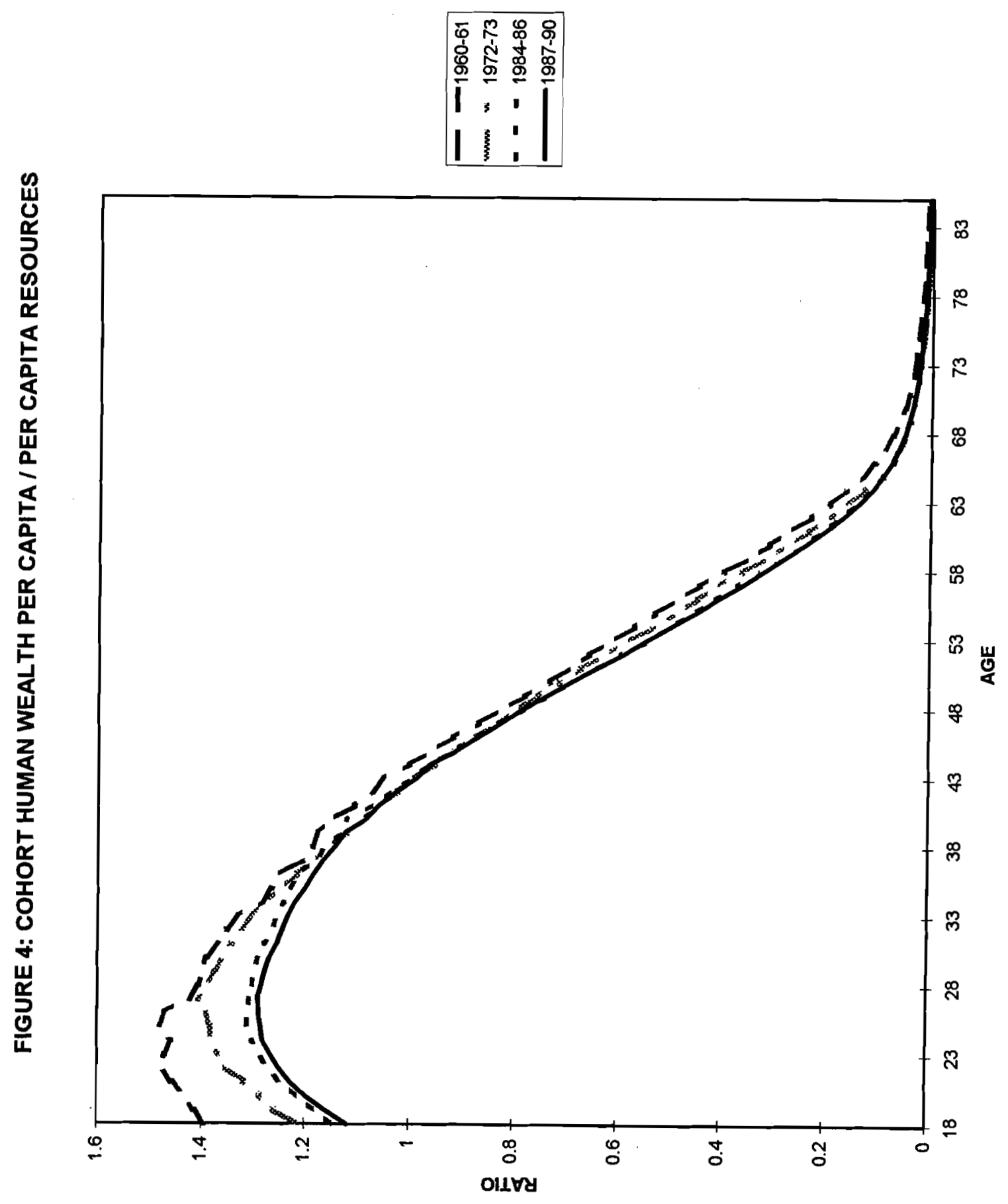


FIGURE 5: COHORT NONHUMAN WEALTH PER CAPITA / PER CAPITA RESOURCES

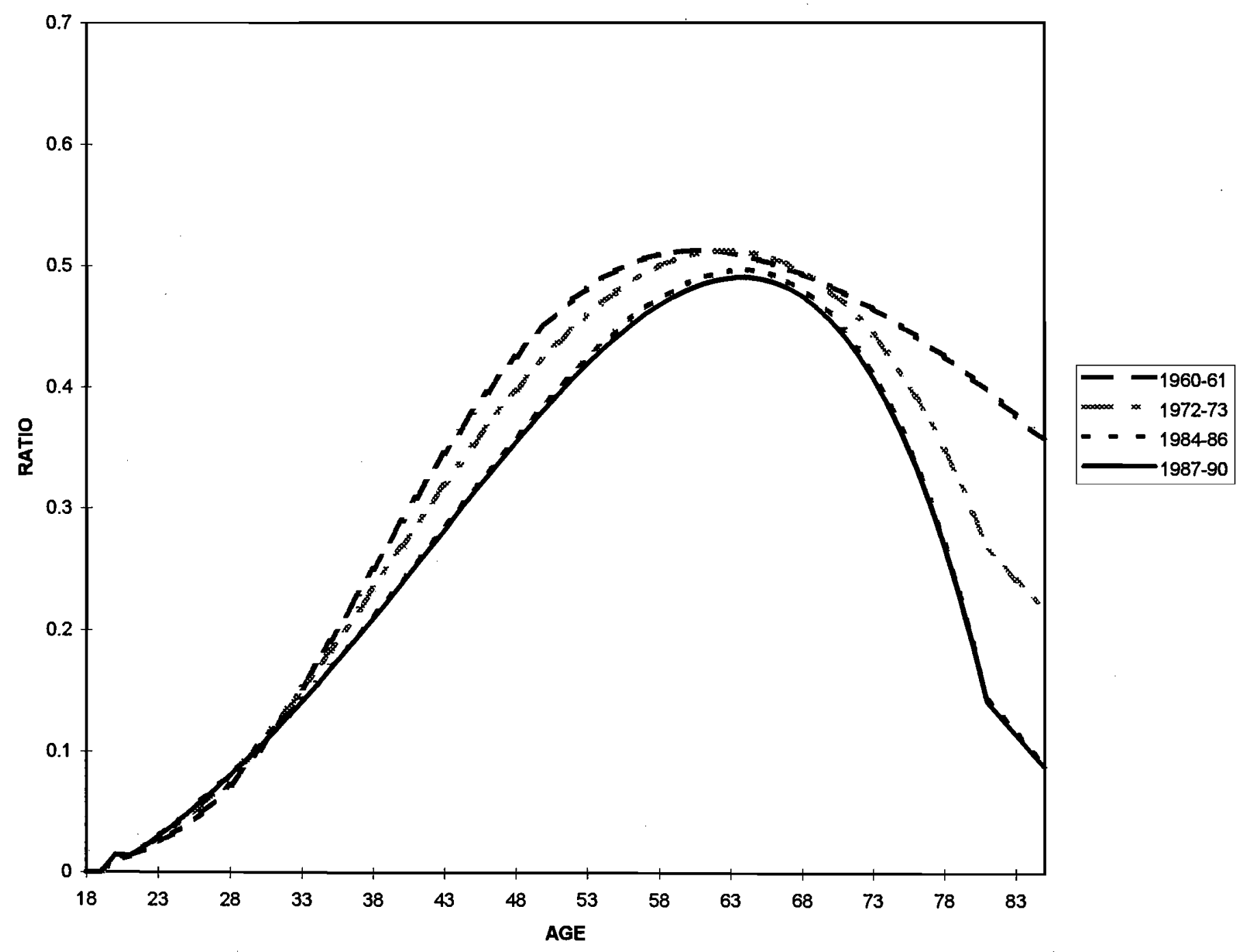

SOURCE: AUTHORS' CALCULATIONS. 
FIGURE 6: COHORT PENSION WEALTH PER CAPITA / PER CAPITA RESOURCES

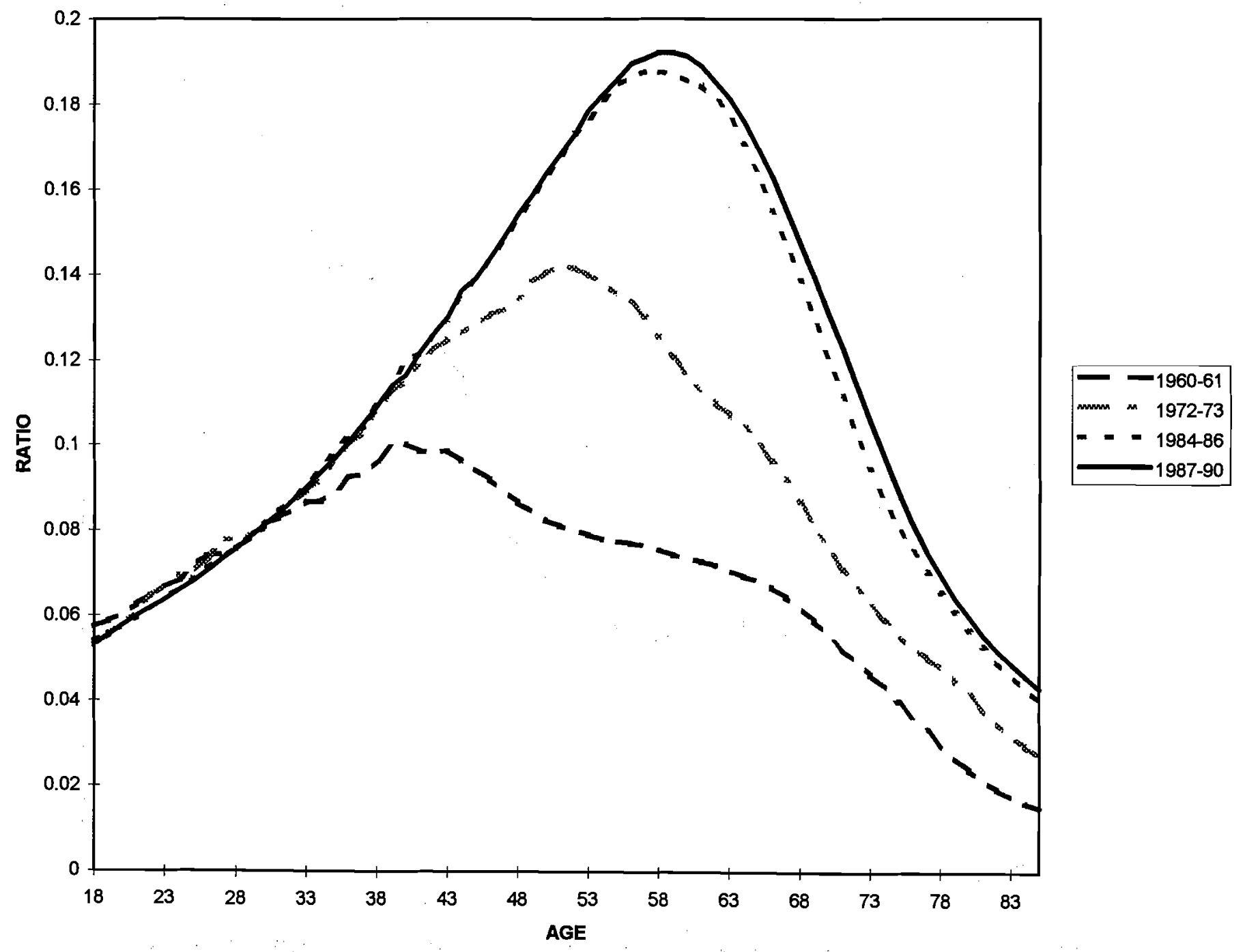



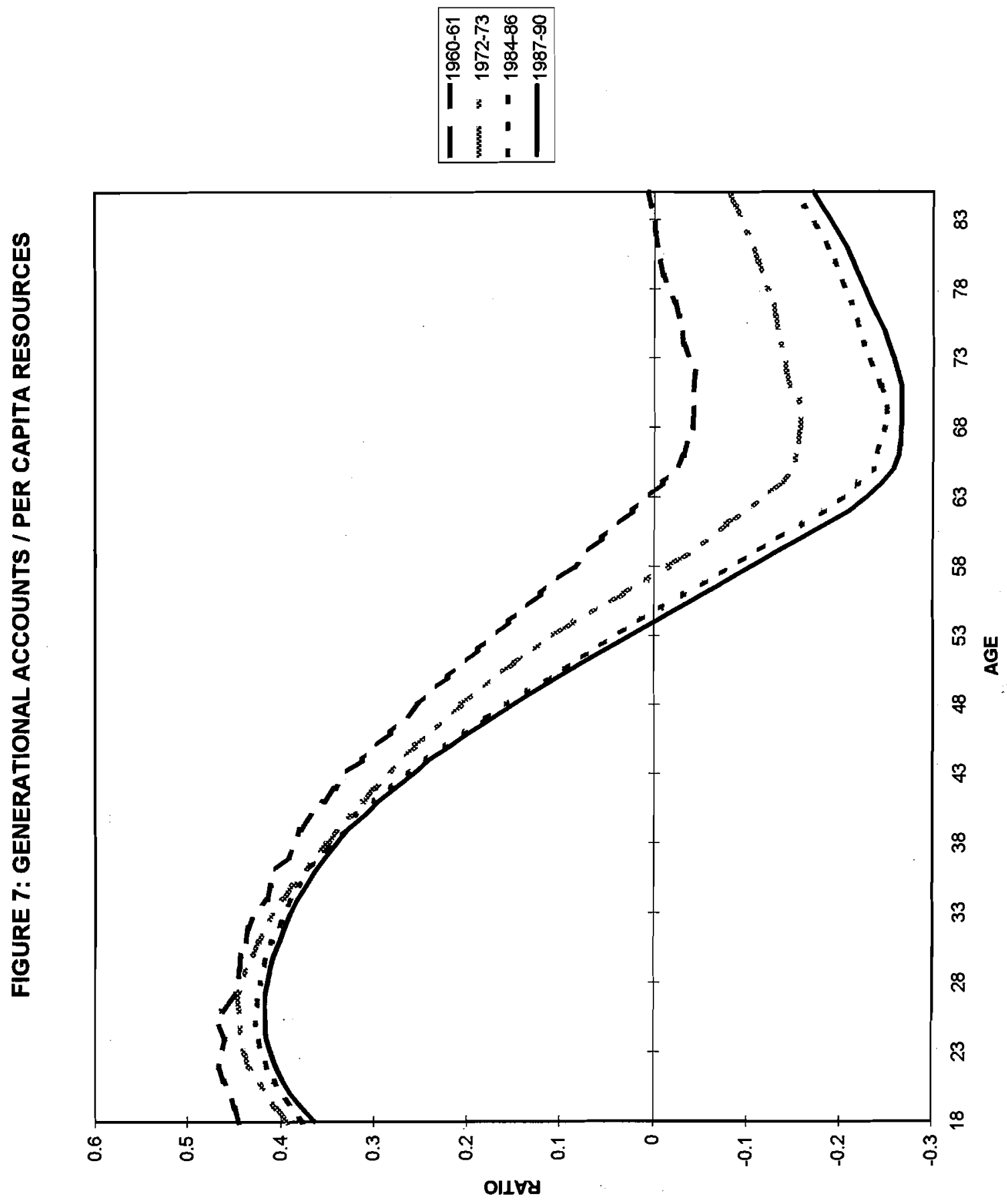


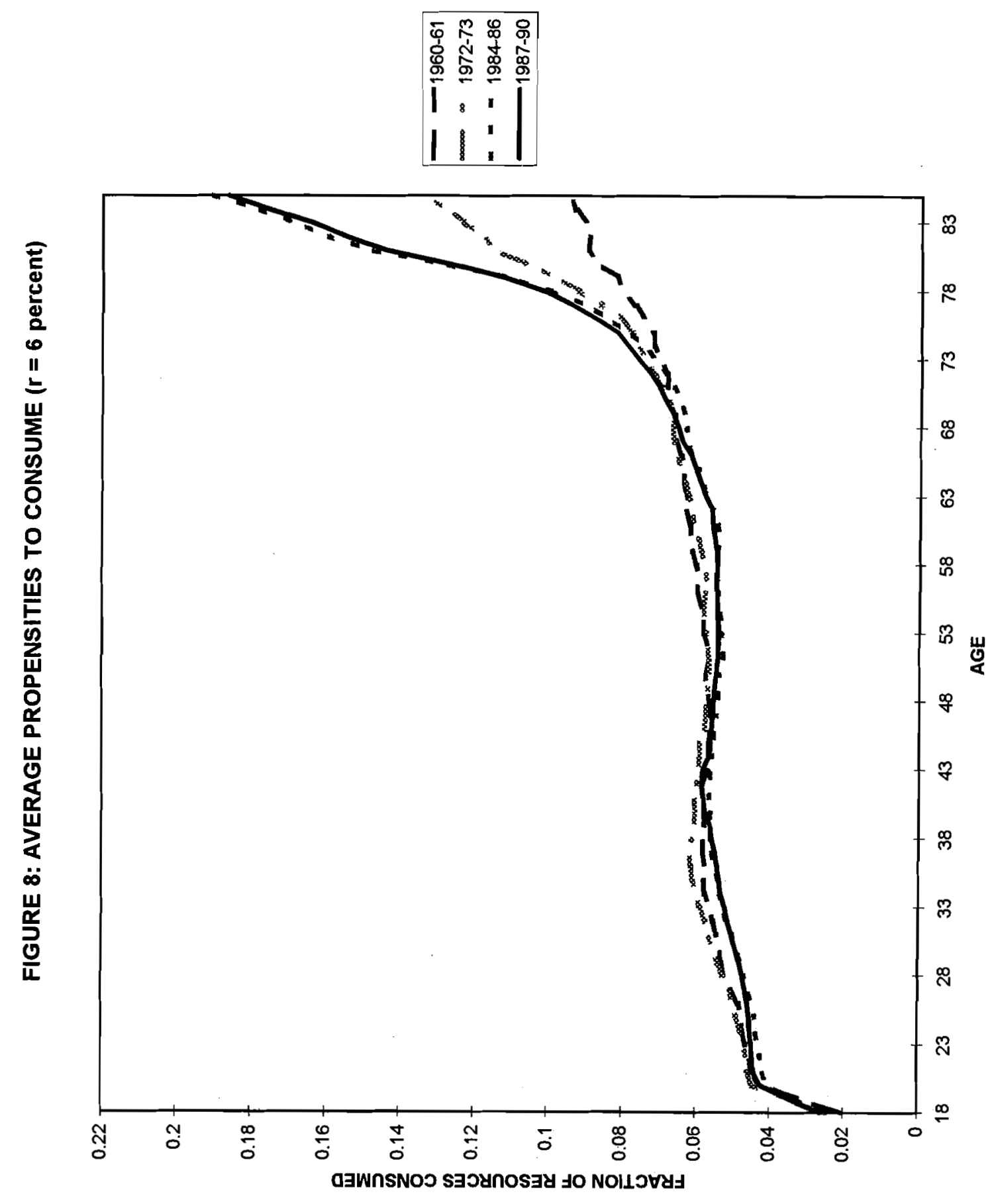




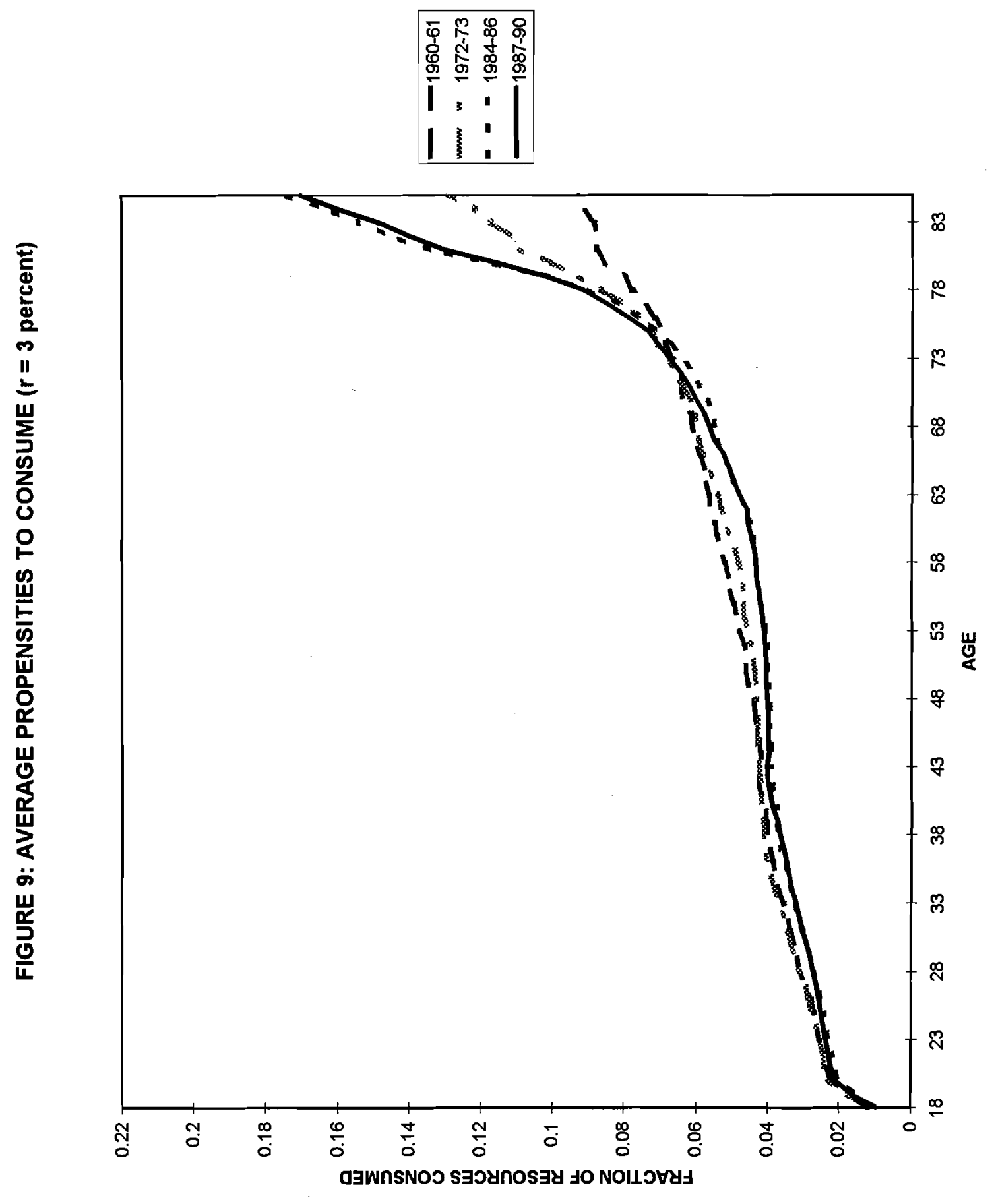



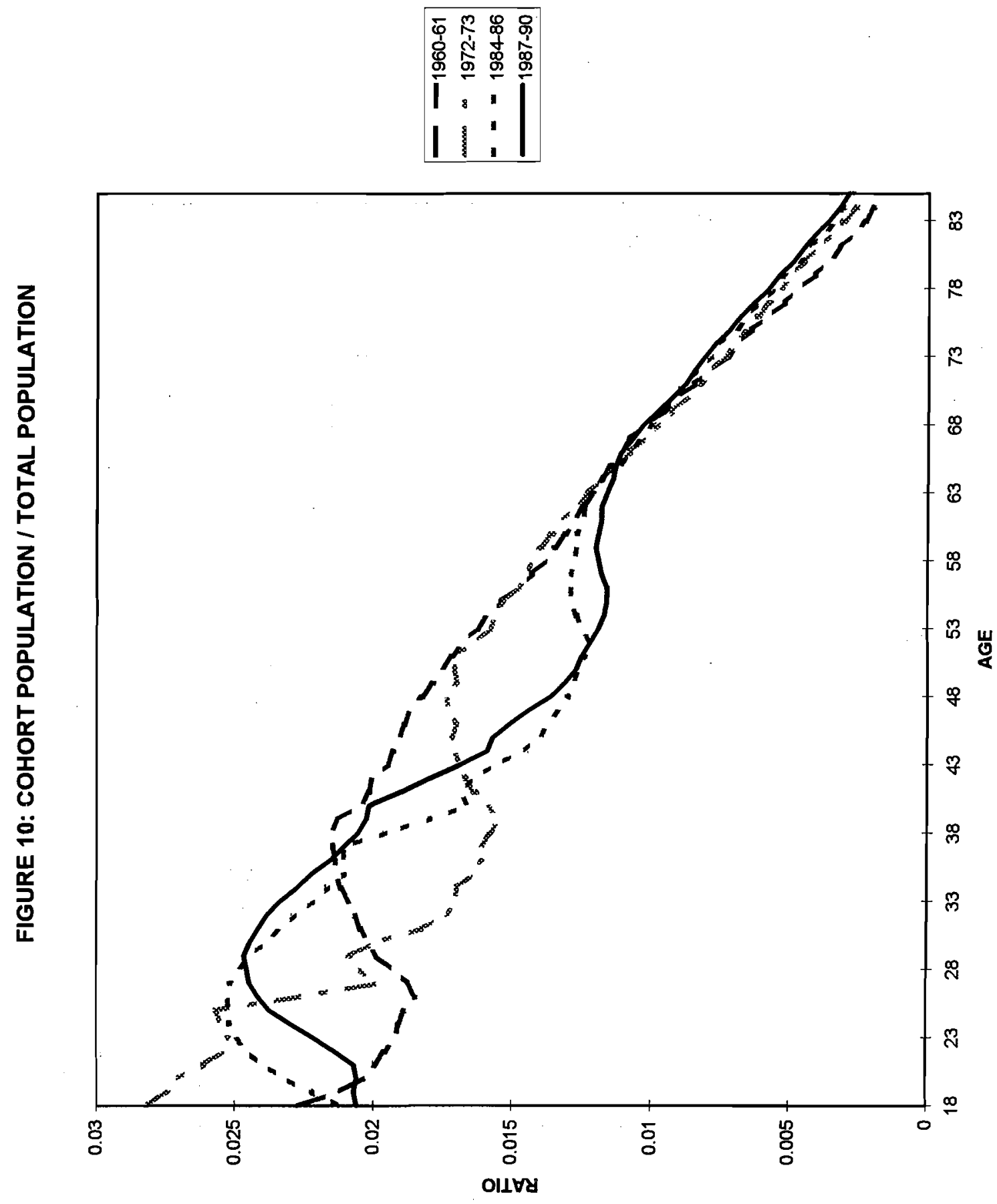